DIW BERLIN

Discussion Papers
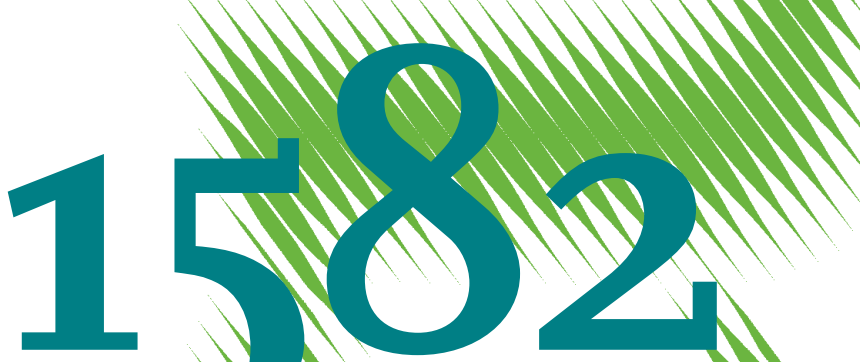

Determinants of Risk Aversion over Time: Experimental Evidence from Rural Thailand 
Opinions expressed in this paper are those of the author(s) and do not necessarily reflect views of the institute.

IMPRESSUM

(C) DIW Berlin, 2016

DIW Berlin

German Institute for Economic Research

Mohrenstr. 58

10117 Berlin

Tel. +49 (30) $89789-0$

Fax +49 (30) $89789-200$

http://www.diw.de

ISSN electronic edition 1619-4535

Papers can be downloaded free of charge from the DIW Berlin website:

http://www.diw.de/discussionpapers

Discussion Papers of DIW Berlin are indexed in RePEc and SSRN:

http://ideas.repec.org/s/diw/diwwpp.html

http://www.ssrn.com/link/DIW-Berlin-German-Inst-Econ-Res.html 


\title{
Determinants of Risk Aversion over Time: Experimental Evidence from Rural Thailand
}

\author{
Lukas Menkhoff*1 and Sahra Sakha ${ }^{\dagger 2}$ \\ ${ }^{1}$ German Institute for Economic Research \\ ${ }^{2}$ Deutsche Bundesbank
}

May 19, 2016

\begin{abstract}
We use a repeated incentivized risk experiment in rural Thailand to test determinants of changes in the level of individual risk aversion over time. We find that risk aversion significantly changes between 2008 and 2013 as a result of macro- and micro-level shocks. Strong macroeconomic recovery following the 2007/08 financial crisis makes people more risk-seeking, whereas macroeconomic normalization thereafter increases risk aversion parameters. On the micro-level, we observe that negative economic and agricultural shocks increase risk aversion. Subjective perceptions of well-being and expectations also play a role but do not drive the macro-micro determinants of changes in individual risk aversion.
\end{abstract}

JEL classification: D01, D81, O12

Keywords: risk aversion, lab-in-the-field experiment, shocks, socio-economic determinants

\footnotetext{
*German Institute for Economic Research (DIW Berlin) Mohrenstrasse 58, 10117 Berlin; and Humboldt University Berlin and Leibniz University Hannover, Germany, Email: lmenkhoff@diw.de, Tel: +49 (30) 89789-435

${ }^{\dagger}$ Research Center, Deutsche Bundesbank, Wilhelm-Epstein-Strasse 14, 60431 Frankfurt am Main, Germany, Email: sahra.sakha@bundesbank.de, Tel: +49 (69) 9566-8626

${ }^{1} \mathrm{We}$ are grateful to participants at the 29th European Economic Association Conference in Toulouse, Spring Meeting of Young Economists in Vienna, the 9th Nordic Conference on Behavioral and Experimental Economics, 2nd International Meeting on Experimental and Behavioral Social Sciences (IMEBESS), the conference of the Society for the Advancement of Behavioral Economics, Lake Tahoe, and at several seminars and workshops for helpful comments and discussions. In particular, we thank Alessandro Bucciol, Rachel Croson, Oliver Gloede, Bernd Hardeweg, Stephen Humphrey, Stephan Klasen, Astri Muren, Holger Strulik, Ferdinand Vieider, and Martin Weber. Financial support by the German Research Foundation is gratefully acknowledged.
} 


\section{Introduction}

Among the various dimensions of individual preference, attitude to risk is particularly relevant as most important economic decisions entail risk or uncertainty. Risk-taking behavior can determine crucial household decisions related to savings and investment behavior, fertility, human capital decisions, and technology adoption. Traditionally, the risk parameter governing these decisions is assumed to be static economic primitives. However, empirical research shows that risk preferences are influenced by individuals' environment and its changes (e.g. Malmendier and Nagel, 2011). We contribute to this literature by analyzing changes to individual risk preferences in a balanced panel over five years.

Our approach aims to address two problematic issues in the literature: First, the few psychological and economic studies looking at changes in risk aversion mostly rely on cross-sectional inferences and/or non-experimental risk data, thus lacking the precise instruments for estimating variations of individual risk aversion over time. Second, clear-cut results on the precise way how shocks modify individual risk aversion (i.e. type of shock, its frequency and intensity) are missing due to data limitations.

As a measure of risk aversion, we employ an incentivized certainty equivalent task as, for instance, in Abdellaoui et al. (2011), Dohmen et al. (2011), Vieider et al. (2015) and Falk et al. (2016). We repeat this risk experiment with a total of 384 individuals in each of three waves over five years (2008, 2010, and 2013). Additionally, we are able to link the experimental results with a large household survey that includes in-depth information on individual experiences with various types of shocks, its intensity and frequency. To the best of our knowledge, this kind of experimental data is unique in terms of sample size and time period.

Regarding potential determinants of risk aversion, a small but growing empirical literature investigates whether idiosyncratic 'micro' shocks (e.g. health shocks, death of relatives and friends, financial losses) and/or covariate 'macro' shocks (e.g. natural catastrophes, violent conflicts) experienced by these individuals trigger persistent preference changes. Changes in the macroeconomic 
environment seem to have a strong and permanent impact on the evolution of individual risk attitude. Malmendier and Nagel (2011) find that the Great Depression has long-term impact on individuals' risk attitude. Similarly, Guiso et al. (2014) show that the recent financial crisis increases risk aversion in the short-run. Both measures of risk aversion (e.g. allocation of wealth to risky assets), however, cannot distinguish between people's beliefs in wealth outcomes and risk preferences. The main results of the impact of natural disasters and violent conflicts are mixed, some report it makes people more risk averse (Cameron and Shah, 2015) while others report the opposite (Eckel et al., 2009; Voors et al., 2012).

At the same time, due to the lack of panel data, there is hardly any evidence on the impact of idiosyncratic or micro-level shocks on changes in risk aversion. The distinction between macro- and micro-level shocks, however, is crucial as the implications for welfare and policy might differ. While the former affects everybody in a particular community or region, the later only affects a particular individual or family in this community. The few studies coming close to investigating this issue look at the impact of changes due to socio-economic characteristics rather than micro-level shocks (Andersen et al., 2008; Chiappori and Paella, 2011). Existing weak results may be downward biased by the limited degree of changes in socio-economic characteristics and by the short time-period over which risk aversion is observed. Thus, it is important to cover a longer time period in a highly volatile environment.

We, therefore, choose the setting in rural Thailand because poor households in an agricultural environment have a higher exposure to idiosyncratic and covariate shocks, such as droughts, floods, and pests, to name a few. At the same time, these people often heavily suffer from such shocks as they have limited resources as shock buffer, and informal institutions cannot fully compensate for these shocks, while formal institutions are often missing (e.g. Dercon and Christiaensen, 2011). Thus we expect that micro-level shocks, if they play a role at all, may become relevant for the target group. Moreover, the experiments started in 2008 when the severe world-wide financial crisis also hit Thailand heavily, such that recovery thereafter and normalization in macroeconomic conditions can be observed. 
Our main finding is that macro and micro-level shocks both have significant impact on measured risk aversion. We show that the large swings in the business cycle affect risk aversion as expected. Going beyond Malmendier and Nagel (2011) and Gusio et al. (2014), we provide experimental evidence that allows us to distinguish between belief in outcomes and risk preferences. Furthermore, we observe that risk aversion increases as the number of negative micro-level shocks experienced by the households increases. Among these micro-level shocks, covariate shocks - classified by the respondents - are of significant importance for risk aversion, while idiosyncratic shocks do not seem to play a role at all, which is in line with the literature. Covariate shocks consist mainly of agricultural and economic shocks, while demographic and social shocks are mainly idiosyncratic shocks. Interestingly, the covariate shocks we measure are very different from the economy-wide macro changes, indicating their finer granularity.

Additionally, we find that changes in the subjective assessments of a household's well-being in the past affect present risk aversion. This also holds true when looking at expectations of future well-being. Since we control for macroand micro-level shocks in a fixed effects model, we are able to interpret these subjective assessments as a mixture of unobserved changes that the household experienced (and we cannot fully control) as well as perceptions of observed past changes and expected changes. These subjective assessments are relevant and largely independent from observed macro and micro changes.

Overall, we contribute to the literature by examining both macro and micro determinants on changes in individual risk aversion using a unified empirical approach. We find that both causally impact individual risk aversion changes. In addition, evidence shows that changes in the subjective assessments of wellbeing seem to be important, but socio-demographic variables are not. These results hold throughout various robustness exercises. We also control for possible biases of endogenous sample selection that are inherent in virtually any panel experiment that allows subjects to drop out of the panel.

Our research is embedded in the growing literature that aims to measure and understand risk aversion and its changes over time. Regarding the repeated experiments on eliciting risk aversion, Hey and Orme (1994) are the first, to 
the best of our knowledge, to examine risk aversion over time. However, the repetition takes place the following days, meaning that the study focuses more on consistency than on variation over time (see Hey, 2001). Many studies on macro-level shocks must rely on cross-sectional data (Voors et al., 2012; Callen et al., 2014). Chiappori and Paiella (2011) use panel data from two waves to look at one change in risk attitude over time. More similar to our research is the study by Andersen et al. (2008) that elicits risk aversion from 253 Danish people and then repeats the exercise with 97 of them between 3 and 17 months later. They find high variation in risk aversion over time, some of which can be weakly explained by changes in personal financial affairs, but there is no link to macro factors. Another related paper is Chuang and Schechter (2015), which uses experimental and survey measures to examine stability of risk, time, and social preferences. They find rather stable results for time and social preferences in terms of the survey items but not for the experimental results for risk preferences. However, the instability of risk preferences cannot be explained by income or other socio-economic characteristics.

The remainder of this paper is structured as follows. Section 2 describes the data used in this research and investigates changes of risk attitude over time. Section 3 presents the descriptive statistics, while Section 4 presents our identification strategy. In Section 5, we examine the determinants of risk attitude changes. Section 6 presents further robustness tests and Section 7 concludes.

\section{The experiment and its results}

This section describes the experiment revealing risk preferences. The experiment is embedded in a larger household survey. We start by describing the household survey in Section 2.1 and the certainty equivalent experiment in Section 2.2. We present the experimental outcome of all three waves in the cross-section in Section 2.3, while Section 2.4 shows the experimental outcome over time. 


\subsection{The household survey}

The experiment is administered as part of a large household survey in the "Impact of shocks on the vulnerability to poverty: consequences for development of emerging Southeast Asian economies" project, which, among others, collects data from approximately 2,000 households in three provinces of Thailand starting in 2007. The household selection process follows a three-stage stratified sampling procedure where provinces constitute strata and the primary sampling units are sub-districts. Within each province, we exclude the urban area around the provincial capital city and confine the sample to the remaining rural areas. Within each sub-district, two villages are chosen at random, in which 10 households are randomly selected through the listing of registered citizens. Overall, the sampled households are representative of the rural areas in the considered province.

The household survey contains detailed information on socio-economic characteristics of the household and respondent including: household demographics, expenditures, credit and savings, landholdings, agriculture, employment, health, education, as well as - and this is crucial for our study - past experiences of micro-level shocks. It also includes details regarding village characteristics, including the number of village institutions and its infrastructure. This data provides a representative sample of rural households in the Northeastern part of Thailand.

Due to capacity constraints, the experiment was conducted in Ubon Ratchathani, the largest of the three provinces surveyed in Northeastern Thailand. The implementation process involved a pilot study with the purpose of reviewing the questionnaire for clarity, with respondents interviewed by a local enumerator face-to-face. All enumerators were changed for each wave. We test for the possibility of enumerator fixed effects and do not find that it affects our results.

During the first wave, in 2008, we interviewed 947 respondents - typically the household head. In 2010, we re-interviewed 909 of these respondents, while in 2013, the last series, retained 851 interviewees. As the sampling unit is the household, the interviewed respondent within the same household may change 
over the years. In our analysis, we employ both the full sample, as well as the specific sub-sample of households where the interviewee did not change across all three experimental waves; we focus mostly on this "repeated sub-sample", which comprises 384 respondents.

\subsection{Description of the experiment}

The experiment is an incentivized certainty equivalent task designed to reveal risk preferences. An important concern in risk preferences elicitation through lottery games is the extent to which subjects understand the instructions. Even if we have selected a simple task, the experiment could be complex to understand, especially for field subjects in a developing country. Since many of our participants have received little education, we provided all participants with clear and visual instructions to make it easier for illiterate subjects to understand the consequences of each decision they made within the game.

The structure of the experiment is given in Table A.1 (more details on instruction is given in Appendix A). It illustrates the basic payoff matrix presented to subjects. The first row shows that the lottery offers a 50-50\% chance of receiving either 0 Thai Baht (THB) or 300 THB and alternatively a safe payoff of 0 THB. The expected value (EV) of this lottery is 150 THB constituting almost one day's unskilled labor wage. Choosing the sure payoff violates the first-order stochastic dominance. The second row, however, already offers 10 THB as safe payoff. This provides the opportunity for very risk-averse individuals to opt for safe payoff over the lottery. The value of the safe payoff is increased in each row by 10 THB so that in the last row one can choose between 190 THB or the lottery. The switching row from the lottery to the safe payoff designates individuals' risk attitude. A risk-neutral subject would switch when the EV of the lottery equals to the safe payoff; that is row 16. As a result, rows below 16 indicate risk-averse behavior while risk-loving individuals would favor rows above 16 .

In the main body of analysis (and thus alternatively to looking at the switching row), we study the effects of experimental conditions in terms of the constant relative risk aversion (CRRA) characterization. The CRRA util- 
ity function is defined as:

$$
U(y)=\left(y^{1-r}\right) /(1-r)
$$

where $r$ is the CRRA coefficient. The dependent variable in the interval regression model is the CRRA interval that subjects implicitly choose when they switch from lottery to safe payoff. For each row in Table 1, we can calculate the implied bounds on the CRRA coefficient. If we assume a constant relative risk aversion (CRRA) utility function the first row becomes:

$$
0.5\left(\frac{300^{(1-r)}}{1-r}\right)-\left(\frac{10^{(1-r)}}{1-r}\right) \geq 0
$$

Where $r$ is the Arrow -Pratt coefficient of relative risk aversion defined as:

$$
-\frac{Y U^{\prime \prime}(Y)}{U^{\prime}(Y)}
$$

The solution is 0.796 . Therefore we conclude that the solution to the above inequality is $r=0.796$. In the second row, again, if we assume a constant risk aversion (CRRA) utility function this becomes:

$$
0.5\left(\frac{300^{(1-r)}}{1-r}\right)-\left(\frac{20^{(1-r)}}{1-r}\right) \geq 0
$$

The solution is 0.744 . We find that an estimate for the coefficient of relative risk aversion for a person who choose Option B is $0.796 \leq r \leq 0.744$. We use the same method to estimate the coefficient of relative risk aversion for all choices.

\subsection{Experimental results in the cross-section}

The cross-sectional experimental outcome for each wave is illustrated in Figure 1. For the experimental result, it is evident that the majority of respondents choose rows below 16, thus explaining the left-skewed shape of the histograms. Second, there is a larger peak at row eleven, i.e. where people seem to be attracted by the safe payoff of a round figure which is 100 Baht. Another smaller peak occurs at row 16, i.e. where the safe payoff exactly matches the EV of 
the lottery. Third, there is another large peak at the very right, i.e. in the domain of risk-loving answers where subjects prefer a lottery with outcomes 0 or 300 Baht to safe payoffs of 190 Baht. This could be an outcome due to the construction of our risk-elicitation task that might have been influenced by censoring at 190 THB (see Andersson et al., 2016). Comparing all three distributions together, risk preferences do not seem to remain stable over time.

\subsection{Experimental results over time}

With respect to individual changes over time, Figure 2 displays the data for the within-sample comparisons that our experimental design allows. The values show the difference between the mid-point of the elicited CRRA interval of the repeated respondents at different points in time. If there were no changes in elicited CRRA then the data point underlying the histogram in Figure 2 would be zero. If the CRRA had increased in the later series, the data point would have been positive. The differences in relative risk aversion for all three waves illustrated in Figure 2 do have a tendency to be negative, indicating a within-sample change towards risk-neutrality and risk-seeking attitude. This evidence confirms the pattern of instable risk preferences in Figure 1.

Pooling over three years, we find a between-subject standard deviation of 0.37 which is smaller than the within-subject standard deviation of 0.46 . This shows that the variation in response due to time is greater than the variation due to individual heterogeneity in subjective risk preferences.

In a further investigation, we look at the correlation between CRRA values elicited at different points in time. In the first regression the dependent variable is the CRRA in wave 3 and the independent variable is the CRRA in wave 1. The results show that there is a significant correlation between the elicited CRRA values in 2013 and those values in 2008 with a correlation coefficient of 0.093 ( $\mathrm{p}$-value of 0.05 ). This is true for the entire sample. If we only take the respondents that could be re-interviewed $(\mathrm{N}=418)$, the correlation coefficient is slightly higher with 0.144 and is significantly different from zero (p-value of $0.06)$.

Coefficients of correlation are slightly higher when we compare waves which 
directly follow each other: regarding wave 2 and wave 1 , the coefficient is 0.104 (p-value of 0.02$)$. When taking only the repeated observations $(\mathrm{N}=616)$, we have a substantial increase in coefficient value of 0.173 (p-value of 0.02 ). Regarding wave 3 and wave 2, we find coefficients of 0.10 ( $\mathrm{p}$-value of 0.03 ) for the entire sample and 0.16 (p-value of 0.02 ) for the repeated sample.

Evidence with regard to the stability of risk preferences over time suggests relative low correlation of risk attitudes (Chuang and Schechter, 2015). Research studying how shocks affect preferences usually starts from the underlying implicit assumption that, in the absence of shocks, preferences would have changed less. One explanation for the low correlation coefficients and, thus, the instability of risk preferences may be that respondents have faced certain shocks that caused their preferences to change in the given time period. We investigate this in the next section. Nevertheless, our correlation results are in line with the study of Guiso et al. (2014), where correlations with at least 100 observations are 0.18 .

\section{Possible determinants of the changes in risk aversion}

In order to examine possible determinants of individual risk aversion we introduce four groups of variables. Section 3.1 presents a large set of sociodemographic and village characteristics. Section 3.2 discusses possible macroeconomic influences on risk aversion. Micro-level shocks of households are presented in Section 3.3. Section 3.4 provides descriptive statistics of well-being and expectation indicators.

\subsection{Summary statistics of individual, household, and village char- acteristics}

In this section, we analyze socio-demographic characteristics of our sample population where we distinguish between the full sample and those individuals who participated in all three waves, the so-called "repeated sub-sample" with 384 respondents.

Table 1.A, Panel A provides summary statistics of individual and household characteristics of our sample (see Appendix B for variable descriptions). For 
the full sample, respondents are, on average, 52 years old. Almost $60 \%$ of the respondents are female. Approximately $63 \%$ are engaged in farming activities; few are self-employed. Over the years, the proportion of farmers increases slightly, while the number of self-employed individuals decreases. This may arise because self-employment is, to some extent, necessity based and, thus, decreases following the 2007/08 crisis. Respondents are typically married, have an average household size of four and low levels of education, i.e. less than six years of schooling. Furthermore, most subjects report having a good health status. Consumption increases significantly following the 2008 crisis period, representing a clear improvement in living conditions. Nevertheless, compared to the rest of Thailand, annual average household consumption is still fairly low $(8290 \$ \mathrm{PPP})$.

We find only small differences between the full and repeated sub-sample. The repeated sub-sample differs from the full sample in terms of age since by definition - people are slightly older (by two years). The repeated subsample also has somewhat less education (on average one quarter of a year). Furthermore, given low levels of education, it is also reasonable that they are less mobile and are mostly farmers when compared to the full sample. Yet, the economic relevance of these differences is minor.

Table 1.B, Panel B provides summary statistics of the experimental results in all three waves and for different subsamples. The average switching row from the lottery to the safe payoff is 7.95 and 8.43 for the full sample and repeated sub-sample, respectively. Despite larger changes over time, the majority of respondents remains risk-averse over time - in line with results in the literature, such as Harrison et al. (2007) for Denmark, Dohmen et al. (2011) for Germany or Hardeweg et al. (2013) for Thailand.

Table 1.B, Panel C displays descriptive statistics for certain characteristics of our 98 villages. Most importantly, we do not find any significant difference of the number of village shocks between repeat- and non-repeated samples. We do not go further into the various variables because we will use this village information later to control for selection bias between the repeated- and nonrepeated-samples. One significant difference between the full and repeatedsamples, however, has to be clarified. Households in the repeated sub-sample 
live in more remote areas that are further away $(0.8 \mathrm{~km}$ more $)$ from the next district capital. We will use this variable later as an instrument to control for attrition bias.

\subsection{Macroeconomic environment}

The macroeconomic environment of Thailand between 2008 and 2013 is characterized by unusual high volatility. In line with other emerging economies that also have largely functioning institutions, the long run growth rate of Thailand is relatively high when compared to advanced economies. Due to a low population growth rate (below $1 \%$ p.a.), most of this high growth translates into high per capita income growth.

Turning to concrete numbers (as reported by the IMF), the $4.2 \%$ GDP growth rate in the year 2007 is a good starting point. Unlike many other emerging economies, Thailand could not shield its economy against the recent world-wide financial and economic crisis, which is reflected in the respective recession growth rates of $1.8 \%$ (2008) and even $-3.0 \%$ (2009). The bottom of the crisis occurs around the second and third quarter of 2009. Thereafter, a new strong upswing takes place leading to GDP growth of $7.8 \%$ in 2010 . The following year is impacted by heavy flooding in the central regions of Thailand, where industrial production is located, resulting in growth falling to $0.1 \%$ in 2011. Again, a strong recovery follows with $6.5 \%$ growth in 2012, and some normalization with $3.1 \%$ in 2013 .

Naturally, the rural areas in Northeast Thailand, where agricultural production dominates, are affected by these developments. In addition to spillovers via demand for agricultural products, financial transfers within families and even within-country migration, there are also heavy price changes for agricultural products. These occur largely in parallel to the overall macroeconomic situation, i.e. many prices crash in 2008 and explode in 2010.

Overall, our first wave in spring 2008 is overshadowed by a massively declining macroeconomic environment, whereas the wave in 2010 is influenced by the strong recovery and positive expectations. This macro pattern seems to be reflected in the median responses to the risk aversion experiment when looking at Figure 1, which shows an exceptional change in 2010. The negative 
environment and outlook in 2008 may lead to more risk aversion, the boom in 2010 to less risk aversion, while the situation in 2013 may represent quite an orderly macroeconomic environment.

\subsection{Summary statistics of micro-level shocks}

The third group of variables, documented in Table 2, Panel A informs about the number, kind, and magnitude of micro-level shocks that households were exposed to before the respective survey. We distinguish between four kinds of shocks: demographic (e.g. illness, death), social (e.g. theft, law suit, conflict with neighbors), agricultural (e.g. drought, flood), and economic shocks (e.g. increase in price of inputs, collapse of business). We also distinguish among these types of shocks between the number of covariate and idiosyncratic shocks. Idiosyncratic shocks are assumed to be uncorrelated across households within a community and, therefore, should be insurable by, for example, informal mutual insurance mechanisms within communities. Covariate shocks on the other hand are correlated across households within the same community and, thus, informal insurance mechanisms within communities should breakdown when exposed to covariate shocks. To differentiate between idiosyncratic and covariate shocks, we ask the respondent to estimate the impact of the particular household shock on others. Response categories are (i) no other household; (ii) some other households; or most other households in the (iii) village; (iv) district; (v) province; or (vi) country. We code shocks of the first two categories as idiosyncratic shocks and the last four as covariate. In accordance with the income and well-being measures, we see that the number of adverse shocks decreases over time. This applies in particular to agricultural and economic shocks, and is also reflected in the decreasing number of covariate shocks, whereas idiosyncratic shocks do not decrease in number to the same extent.

Another important aspect is to distinguish between covariate shocks and general changes on the macro-level. While conceptually, they appear to be similar, its impact on the livelihood of the people differ substantially (Townsend, 1995; Dercon, 2002). A macro shock, such as low rainfall, may harm production on certain fields within a region but not all communities and households must necessarily be affected. It depends strongly on soil type, slope and crop 
grown. Similarly, a flood will affect only low-lying fields of particular households or villages and may not necessarily affect the whole region, whereas landslides may destroy particular fields, while others may be left completely unharmed. Therefore, we distinguish the impact of covariate shocks and fluctuations on the macro-level, by using this specific household-level questionnaire.

We find that covariate shocks are significantly different from the general change in the macroeconomic environment since the spread of distribution of covariate shocks on households is highly unequal. A large share of respondents $(60 \%)$ did not experience any covariate shocks, while $5 \%$ experienced up to six covariate shocks over the three waves. Due to limited data availability, few studies attempt to estimate the relative importance of covariate shocks (see e.g. Dercon and Krishnan, 2000). Their estimation shows that covariate shocks have a larger and more significant impact on households consumption and vulnerability than idiosyncratic shocks.

\subsection{Summary statistics of subjective well-being measures}

Most economic decisions involve uncertainty and are therefore shaped not only by preferences but also by expectations of future outcomes. Understanding the expectations that individuals have is thus critical for understanding their behavior and for modeling the effects of policies. For example, several explanations could rationalize why youths in developing countries do not go to school. One possibility is that they expect low returns to schooling. Another alternative is that they face high attendance cost. Without data on expectations we cannot separate these two explanations, yet doing so is important for designing policies that promote schooling (Delavande et al., 2011). Our measure of subjective well-being uses a Likert-scale ranging from one to five and addresses perception of past and future well-being outcomes which both goes beyond the macro and micro information discussed before. Table 2, Panel B displays the subjective assessment of the respondent's perceived in well-being (compared to the past) and expected changes in well-being in the future. In each wave we ask subjects to respond to two questions about their household's development: "Do you think your household is better off than 5 years ago?" and "Do you think your household will be better off in 5 years?" 
As higher values indicate a worsening situation, these variables are labeled here as "perceived ill-being (past)" and "expected ill-being (future)". While the first variable indictates how well the household feels at the time of the survey compared to the past, the latter variable indicates the view of the economic condition of the household in five years time. The decreasing values over the years show that respondents feel that their situation is clearly improving over time whatever specific question or reference point we use. The repeated sample is a bit less positive about changes in their economic situation than the full sample (which fits to its slightly older and less mobile sample population compared to the full sample).

\section{Identification strategy}

In this section, we present our identification strategy in order to demonstrate the impact of four groups of variables on changes in risk preferences: these groups are individual socio-demographic characteristics, macro-level fluctuations, the experience of negative micro-level shocks and subjective well-being measures.

The novelty of our study is that we use panel data. Most research on timevarying risk aversion is based on cross-sectional data (e.g. Binswanger, 1981; Donkers et al., 2001; Harrison et al., 2010) and hence is subject to the usual limitations associated with such data. By presenting evidence from a representative panel data set, we further can infer the direction of causation - do shocks lead to higher risk aversion or higher risk aversion to higher shocks (i.e. shirking of the adaptation of new technologies, insurances etc.)? Although it is difficult to solve the endogeneity problem fully, we argue that shocks are exogenous and unexpected across all households. Further, with repeated observations for the same individual, it becomes possible to control for unobserved time-invariant individual specific effects.

Our identification strategy exploits the determinants of changes in risk preferences, while controlling for the four groups of variables introduced above 
using the individual fixed effects model. More formally, we estimate:

$$
Y_{i, t}=\alpha t+\beta 1 \text { Shock }_{i, t}+\beta 2 W_{\text {ellbeing }}, t+\beta 3 X_{i, t}+\pi W_{i}+u_{i, t}
$$

where $\alpha t$ is the time effect, and $Y_{i, t}$ is the measure of risk preferences using a constant relative risk aversion interval computed from the switching row of individual $i$ at time $t$. $X_{i, t}$ are observed time-varying individual characteristics. The vectors of controls include gender, age, years of education, marital status, household size, health status and log per capita consumption. $\pi W_{i}$ captures any time-invariant unobserved heterogeneity and $u_{i, t}$ is the error term. The coefficient $\alpha t$ captures the time-varying macro-level changes on risk attitudes, $\beta 1$ measures the effect of micro-level shocks on risk preferences while $\beta 2$ measures the effect of changes in subjective well-being measures on the shift in distribution of risk preferences. We expect a positive coefficient for micro-level shocks and well-being measures on the CRRA interval, i.e. the more shocks an individual is exposed over the time, the higher the risk aversion.

We employ the fixed effects estimation in the regression above to remove time and individual fixed effects. The Hausman test statistic of 35.25 leads to the rejection of the model without fixed effects. A remaining major econometric issue is the possible presence of unobserved fixed effects $\pi W_{i}$ that challenges a causal interpretation of results. It can well be the case that the basic part of risk preference $Y_{i, t}$ is driven by some unobserved individual characteristics such as physical and mental stress tolerance. At the same time, these unobserved individual characteristics could be correlated with $X_{i, t}$ through factors such as residential sorting. In order to be able to infer a clear causal relationship between the exposure of shocks and changes in risk aversion, we control whether attrition and selective migration undermine our identifying assumption; these do not (see robustness checks in Section 6).

\section{Estimation Results}

In order to examine the possible determinants of individual risk aversion we proceed in three steps. Section 5.1 presents the most important determinants of risk aversion. Section 5.2 looks deeper into the different types of shocks 
that may increase risk aversion and Section 5.3 presents the determinants of changes in the levels of risk aversion for subsamples.

\subsection{Estimates of the fixed effects model on determinants of risk preferences}

Columns 1-5 in Table 3 present the results from a simple fixed effects model where the dependent variable is the constant relative risk aversion interval. All specifications allow for clustering of standard errors at the village level. In addition to the time effects we also include district fixed effects to control for any potential differences at the district level that might affect our results, such as public goods provisions, government programs and/or geographic differences.

Column (1) in Table 3 includes several relevant individual characteristics in the regression. Note that our within estimator regression automatically nets out the influence of time-invariant characteristics (e.g. gender). The estimate shows that large changes in levels of risk aversion are not systematically related to changes socio-demographic characteristics except consumption and marital status.

In column (2) we include time-varying macroeconomic influences via the time fixed effects and find that consumption becomes insignificant, which is similar to the findings of Chiappori and Paiella (2011) and Meier and Sprenger (2013). The latter study shows that distributions of time preference parameters are independent of changes in socio-demographics, income, unemployment and family composition. We find that fluctuations in the macroeconomic environment captured by the time fixed effects are significant in explaining changes in risk aversion over time; these variables compensate for the influence from consumption, which becomes insignificant. Tables 1 and 2 show that between 2008 and 2010 there has been an improvement in the overall living condition of the households (i.e. fewer shocks, increased well-being etc.), which is reflected in the regression. The year coefficients are all comparisons with 2008 and are both negative. Thus, ceteris paribus, the risk aversion of our respondents decreases significantly in 2010 and 2013 when compared to 2008.

In the next column (3) we keep the key socio-demographic variables and include the number of micro-level shocks reported by the household while ex- 
cluding the time dummies. First, we continue to find a weak impact of socioeconomic characteristics on changes of risk preferences. Second, we find that an increase in the number of (negative) micro-level shocks makes the subject more risk averse. This is statistically significant at the $1 \%$ level.

In the column (4) we also include, in addition to the socio-demographic variables and number of micro-level shocks, subjective well-being indicators. We find that both the predictive power of the number of micro-level shocks and the well-being indicators seem to be consistently correlated with higher levels of risk aversion. Risk aversion is higher with a pessimistic outlook of the future (coefficient of 0.089 ) and with a pessimistic perception of past developments (coefficient of 0.086).

In the last column we include all determinants of changes in risk aversion in one regression. In this case, all the coefficients of interest decrease slightly. For example, an increase of micro-level shocks by one unit increases risk aversion by 0.048, while in column (3) it increases risk aversion levels by 0.062. Similarly, we find that a worsening of the households expectation over time increases the risk aversion interval by 0.060 when we include all the variables of interest in one regression that, in contrast to column (4), represents a decrease of 0.020 percentage points. Furthermore, we also find that with the exception of the year dummy 2013, significance levels remain stable. Yet the previous findings of columns (1) to (4) remain consistent. All formerly significant determinants, i.e. macroeconomic environment, micro-level shocks and subjective well-being play a role in determining changes in the level of risk aversion.

Given these findings, it is legitimate to ask which kinds of micro-level shocks might have affected the risk aversion of the respondents.

\subsection{Impact of various micro-level shocks on changes in risk aversion}

In this section we replace the general variable "number of micro shocks" from Table 3 by disaggregating information about the kind of micro shocks. In Table $\underline{4}$ column (1) we include four shock types in our regression to investigate what type of shock contributes to changes in individual risk attitudes. We again include district and year fixed effects using the within estimator. Coefficients other than shock types keep sign and significance as in the benchmark result 
in Table 3. Regarding shocks, all types (i.e. demographic, agricultural, social, and economic shocks) seem to increase risk aversion, which makes sense given the restriction to "negative" shocks. The strongest effect for an increase in risk aversion comes from economic shocks with a magnitude of 0.17 and p-value $<$ 0.01. We also find a statistically significant effect for agricultural shocks $(0.06$, p-value $<0.05)$.

Column (2) investigates the impact of the magnitude of shocks on changes in risk attitude because the severity of shocks may also impact risk attitude. We rely on respondents who classify the severity of shocks they were exposed to as having low, medium, and high impact. We find that high impact shocks significantly increase risk aversion with a coefficient of 0.011 and p-value $<$ 0.01. Furthermore, we also find that medium impact shocks affect changes in risk aversion, however, with a lower magnitude than high impact shocks $(0.04$, p-value $<0.05)$. By contrast, and consistent with expectations, shocks that are classified as "low" do not have any impact on risk aversion.

In column (3), we see that only covariate shocks have a significant impact on changes in risk aversion, whereas the effect from idiosyncratic shocks is smaller and the corresponding standard deviation is larger. This largely reflects results from column (1) as (statistically significant) agricultural and economic shocks are also more often covariate shocks. It must be noted that most of the changes on the levels of risk aversion is driven by covariate shocks on the village and district level. One could assume that covariate shocks on the provincial or country level should be related to fluctuations in the macro environment. In our case, however, we find that most aggregated covariate shocks reported by the households on the provincial and country level only count for 2-3\% in 2010 and 2013 (in 2008 it was 6\%). We do not find evidence that covariate shocks reported on the provincial or even country level are highly correlated with the macro environment and, thus, could be replaced. The strongest impact of covariate shocks, therefore, can be contributed to shocks that household face primarily on the village level and to a smaller extent to the district level. This is in line with the literature concerning the adverse effect of covariate shocks within a village when, for instance, informal insurance mechanisms break down. 
The major result for this study is that the use of panel data and fixed effects models corroborates the hypothesis of large effects of various kinds of negative micro-level shocks on risk aversion. We find that specifically the intensity of the shock and shocks being of economic and agriculture nature seem to explain increases in the level of risk aversion.

\subsection{Impact of shocks on changes in risk preferences for vulnerable subpopulations}

Indeed, if heavy micro-level changes impact the degree of risk aversion, then these effects should be stronger for more vulnerable subpopulations. We hypothesize that individuals will be more affected if they are less insured and have lower income, which implies higher exposure against shocks.

In Table 5 we run the same regression as in Table 4, however, for subpopulations. In Panel A households are split according to the number of voluntary insurances a household possesses. Rural households in Thailand have a range of voluntary insurances including life, property, funeral, livestock, disability and health insurances (while a system of universal health care exists). The distribution is highly uneven. A large share of households possesses up to two insurances (32\% respectively) while few households possess more than 5 insurances (10\%). We hypothesize that lower levels of insurances are correlated with higher vulnerability and, thus, greater exposure to shocks that might have a stronger effect on changes in risk aversion.

We find that respondents' risk aversion changes more for those who report having less insurance. In the first column, we find that having lower amounts of insurances makes them more vulnerable not only to economic but also to agricultural shocks; this is statistically significant at the $10 \%$ significance level. Covariate shocks also seem to be important. For this group, both high impact and medium impact shocks seem to be crucial. For the second group only economic shocks seem to be significant, while for those having more than five insurances (column 3), none of the micro-level shocks significantly explains changes in risk aversion. Hence, the more insurances people have, the lower is, tentatively, the impact of micro-level shocks.

In Panel B we look at the income distribution of our sample and split it 
into five quintiles. This way, we are able to compare those in the bottom $20 \%$ of income distribution with those in the middle (40-60\%) and top of the distribution (top 20\%), while we do not report results for the remaining two groups (20-40\% and 60-80\%). The lowest group in our income distribution has an average annual income of around $815 \$(\mathrm{PPP})$. The median is slightly higher (1296\$, PPP). It seems evident that the poorest $20 \%$ in the income distribution live very close to the current poverty line. Those households living in the median income group possess an average annual income of around 5383\$, PPP. The top $20 \%$ of the distribution have an annual income of $(9135 \$)$. Due to these large differences, we hypothesize that households will be more affected if they have lower income since they cannot afford to implement risk-mitigating activities and, thus, may be more vulnerable to micro-level shocks.

We find that for households in the bottom $20 \%$ of the income distribution, economic shocks mostly affect changes in risk aversion (5\% significance level). For the middle income households, negative social (i.e. theft, law suit) and agricultural shocks play a significant role, while economic shocks are irrelevant for explaining changes in risk aversion. As expected, we do not find any impact of any kinds of micro-level shocks on risk aversion for the wealthiest income group. Consistent with the finding in Panel A, we find that the magnitude of micro-level shocks plays a role. An explanation is that higher income groups also report higher income and asset loss due to shocks compared to lower income groups, which might have an impact on their risk preferences.

These results provide further insight into the effectiveness of insurances (as alternative to having higher income) in reducing economic insecurity and the impact of negative income shocks in developing countries. Insurance instruments can be one of many options in managing risks of unanticipated microlevel shocks, thus reducing vulnerability. Overall, we find that having a low income and lower insurance increases the influence of micro-level shocks which in turn increases risk aversion. 


\section{Robustness}

In this section, we investigate the robustness of the main findings by providing further sensitivity analyses. First, we test whether attrition influences our results (Section 6.1). Then, we test for selection bias (6.2). In Section 6.3 we analyze whether the micro-level shocks may be mainly channeled via income. Next we alter the dependent variable by using the switching row of the individual experimental decisions (Section 6.4). In Section 6.5 we test whether results are driven by outliers.

\subsection{Attrition and the stability of preferences}

The repeated sub-sample of 384 is clearly a selected sub-sample. For the purpose of this study, selective attrition could be problematic if it is correlated with the temporal stability of risk preferences. More formally, attrition bias will occur if the error term in the equation of interest is correlated with the error term in the selection or attrition equation. The selection model, therefore, relies on identifying a set of instrumental variables, $z$, which are correlated with attrition but not with $\varepsilon$ (Heckman, 1979).

First, we test whether attrition is random (see Becketti et al., 1988; Fitzgerald et al., 1998). We test for non-randomness by regressing the repetition of the experiment with socio-demographic (i.e. age, employment status, household size), some village level (i.e. number of shocks, number of village inhabitants, distance to town) and specific experimental characteristics (i.e. payoffs) in the previous waves. We also test whether the last switching row is correlated with the winnings in the previous waves and found no statistically significant results.

The variable that is a significant predictor of attrition is the age of the re-

spondent ( $\mathrm{p}$-value $<0.01$ ). The younger the respondents, the more likely are they to stop participating which might be related to the higher possibility of moving easier between jobs or migrating to the city. Furthermore, household size, income, worsening of health, and distance to town are explaining attrition. Being a farmer reduces the probability of attriting which is related to lower mobility. The resulting Chi-squared statistic of 39.26 with 12 degrees of 
freedom indicates these variables are jointly statistically different from zero at the highest level of significance $(\mathrm{P}$-value $<0.01)$. We conclude that these variables are significant predictors of attrition. The result indicates that attrition is non-random, we proceed using a Heckman selection model.

For this, we need to find a variable being orthogonal to stability of preferences but correlated to the probability of attrition. It is helpful that we have the information of distance to the nearest district town that might be orthogonal to risk preferences but may have an impact on attrition. Table 1, Panel $\mathrm{C}$ indicates that distance does indeed correlate with attrition (We do not find the same result for the distance to the provincial capital of Ubon which on average is $61 \mathrm{~km})$. Hence, we can use distance as an exogenous determinant of sample attrition and check for biased estimations of risk preferences due to sample attrition.

In order to establish a baseline for evaluating the influence of demographics and selection on the stability of risk attitude, column (1) of Table 6 estimates pooled-OLS regressions of CRRA in 2013 on CRRA in 2008 with a constant. The procedure is similar to Andersen et al. (2008). Column (2) includes socioeconomic characteristics included in Table 1. Preferences remain significantly correlated over time. Column (3) shows estimations of the Heckman 2-step procedure to control for selective attrition from the study. We do not consider a permanent unit non-response since some individuals missing from wave 2 reappeared for the last wave. This means that our sample increases from the repeated sub-sample of 384, who repeated our experiment in all three waves, to 471 respondents who participated in 2008 and again 2013, the first and last waves.

As a first step, the inverse mills ratio is generated from the probit regression of non-random attrition including the distance to the next district town, number of inhabitants, and the number of village shocks. Under the assumption that distance is orthogonal to preference stability, column (3) identifies the temporal correlation in risk preferences controlling for stability-driven attrition. We regress CRRA2013 on CRRA2008 including the newly-generated inverse mills ratio as a sampling weight. We see that controlling for sample attrition does little to the estimated correlation. 
Looking at the three exogenous characteristics in column (2) and (3), i.e. gender, age, and height (see Dohmen et al., 2011), we find that using the Heckman selection model yields different results. Gender seems to be significant and positively correlated with risk aversion which is in line with the literature documenting differences in the risk preferences of men and women (Croson and Gneezy, 2009). Age seems to be significant in column (2) but the coefficient sign is theoretically surprising and we will indeed see later that this coefficient is not robust as it basically captures the effect from the later waves, which are not controlled for here. Nevertheless, the results so far suggest relatively low correlation of risk preferences over time even after taking into account individual characteristics and sample attrition.

\subsection{Selection bias}

Besides attrition bias, there is another principal issue confronting attempts to establish the causal effect of micro-macro shocks on risk preferences using panel data, i.e. selection bias where individuals may locate according to their preferences. In our case risk-averse individuals may select areas that are less prone to shocks. For example, wealthier individuals may choose to live in villages with less exposure to shocks and, hence, are more likely to choose the riskier option because risk-seeking attitude and wealth are positively correlated in the literature. Hence the causal effect between shocks and risk may be distorted due to the wealth effect.

In the same manner, one can argue that villages that experienced a great number of micro-level shocks in the past years might be different from villages that did not experience any number of shocks. For instance, villages that have more shocks may have less provision of public goods, infrastructure etc., again causing a negative correlation between number of shocks and risk aversion that is not causal. We follow the approach by Cameron and Shah (2015) in order to control for selection bias.

Table 7 shows pooling across villages that there is no significant difference between villages that experienced micro-level shocks and those that did not. In Panel A we provide village level characteristics and see whether villages that experienced shocks are significantly different from villages that did not have 
a shock in the past 5 years. Although a considerable time has passed, we do not find any difference for variables that are plausibly exogenous to exposure to shocks.

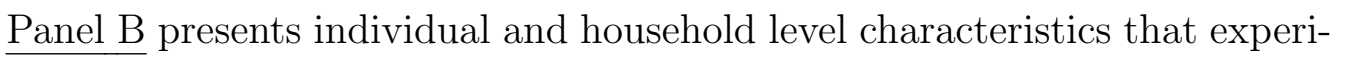
enced or did not experience a shock over the past 5 years. Most importantly, we find no significant difference in wealth or consumption between individuals who experienced or did not experience any kinds of shocks, thus giving us an indication that the wealth effects on changes in risk attitude may be negligible. We do, however, find a difference in the exposure of shocks in terms of gender (women seem to be more vulnerable to shocks), age, household size (interestingly, more shocks are related to a greater number of household size) and health (those with a shock report higher values of sickness).

To conclude with, we can exclude the relevance of two possible confounding factors - attrition and selection bias. Thus, we argue for a causal interpretation of the impact of the number of shocks on changes in the level of risk preferences.

\subsection{Disentangling the effect of income and shocks on changes in risk aversion}

One possible interpretation of our result is that changes in risk preferences are driven by changes in income or wealth that accompany unanticipated microlevel shocks, particularly in the presence of imperfections in the credit and insurance market (Jappelli and Pistaferri, 2010). If the experience of negative shocks of a household results in a reduction of income opportunities; it could change risk aversion. Consequentially, this means that changes in risk preferences cannot solely be attributed to micro-level shocks but also to income and wealth shocks. Given major implications of shocks on income, we try to disentangle income and shock effects on changes in risk aversion.

Table 3 showed that while the exposure to micro-level shocks determines variations in risk aversion, consumption does not seem to play a role. However, to examine the role played by income changes more closely, we include further variables from the household survey. In our dataset, households were also asked to report the value of asset lost due to the shocks they experienced 
as well as the amount of financial aid received (if any). The reported average asset loss due to micro-level shocks is $3 \%$ for all households in the past 5 years.

Table 8 runs the same regression as Table 3 using only the number of economic shocks since it was successfully determining changes in risk aversion. We also include additional controls for the log per capita consumption, namely asset loss due to shocks and the amount of financial assistance received. This allows us to examine if the number of economic shocks is still a major determinant after controlling for both a positive income shock due to financial assistance and a negative income shock due to a loss in assets. As anticipated, the higher the level of asset loss, the higher is the level of risk aversion, which, however, is statistically insignificant. In contrast, throughout columns (1) to (3), we see that the increasing number of economic shocks occurred in the household is still significantly related to changes in the levels of risk aversion. The magnitude of the negative effect of economic shocks on risk aversion remains highly significant at the p-value $<0.05$. In addition to that it seems that the time dummy 2010 is also statistically significant in this model. Noticeable is also an increase in the within R-squared that is higher than in Tables 3 and 4, indicating that the inclusion of asset loss due to shocks and remittances increases the explanatory power of our model. The bottom line from Table 8, however, remains that the households severely affected by micro-level shocks, still become more risk-averse over time.

\subsection{Determinants of changes in risk attitude using switching row}

In the previous analyses, we assume that responses to the experiment follow a CRRA utility function. In the context of utility, risk aversion is equivalent to concavity of the instantaneous utility function, and if one is willing to make particular assumptions about the functional form of utility, it is possible to calculate risk preference in terms of a parameter describing curvature. This calculation uses the assumption that utility is defined only over outcomes in the experiment, rather than over final wealth levels. Thus using the CRRA as a dependent variable requires making an assumption.

Therefore, as an alternative we allow risk attitudes to enter non-parametrically. Instead of taking the midpoint of the CRRA interval as the dependent variable, 
we use the row at which the respondent decided to switch from the lottery to the safe payoff. Low values indicate risk aversion that differs from the CRRA where negative values indicated risk-seeking preferences.

What can be inferred in Table 9 is that all variables from Table 4 are still robust. Most importantly, experiencing more micro-level shocks over time increase levels of risk aversion. Furthermore, if respondent's become more pessimistic over the years they also are more likely to be become more risk averse. We also observe a partial impact of general macroeconomic volatility here. It seems that including year dummy 2010 explains a significant decrease in the levels of risk aversion at the $1 \%$ significance level while the coefficient for the year 2013 is insignificant.

In Table 10 we investigate the effect of different kinds of micro-level shocks on changes in risk aversion using the switching rows. We find that coefficients on economic and agricultural shocks as well as high magnitude shocks still significantly explain increases of risk aversion over time. Macroeconomic volatility also remains significant.

Taken together, using the switching row, we qualitatively confirm results from Section 5 (using CRRA).

\subsection{Determinants of changes in risk attitude eliminating exterme responses}

Using the switching row of the certainty equivalent task allows us to generate household-specific risk-aversion intervals mean values of the upper and lower bound of the CRRA for each switching row. We described the method in more detail in the Section 2.2. In this section, our regressions drop the most risk-averse choices of the individuals, hence the CRRA interval 0.796 to $\infty$ or switching row 1 . This way, we ensure that changes in the levels of relative risk aversion due to shocks are not only driven by very risk-averse responses. We find that our main empirical results are not sensitive to the choice of lower switching rows. This is shown in Table 11, which replicates results from Table 4 and finds that micro-level shocks - particularly economic shocks - are still robust in explaining variations in risk aversion. Overall, we do not find that our main results are driven by extreme risk averse responses. 


\section{Conclusion}

This research is, to the best of our knowledge, the first to repeat an incentivized risk experiment with a larger group of individuals over a period of several years. It examines macro- and micro-level influences on changes in risk aversion over time. Using panel data, correcting for attrition and selection bias, we try to establish a causal relationship. The risk experiment is conducted with about 900 subjects in each of the three waves over a period of five years. Due to changing participation within households and attrition of households, we focus on a sample of 384 respondents who participated in all three experiments over a period of five years.

We find that macro and micro determinants significantly change risk aversion over time. The country-wide macroeconomic fluctuation in Thailand had a plausible impact on risk aversion of the rural population. First, we observe high levels of risk aversion during the 2007/08 global financial crisis. Second, we find decreasing levels of risk aversion during the phase of recovery in 2010, which is followed by a return and "normalization" of levels of risk aversion thereafter. In addition to this macro effect, we find a strong and significant relationship between the exposure to adverse micro-level shocks and increasing levels of risk aversion.

This is an interesting result because earlier empirical studies (Townsend, 1994; Jalan and Ravaillon, 1999; Dercon and Krishnan, 2000) show that macroeconomic shocks have a larger and more significant impact on households' livelihood than idiosyncratic or household-level shocks. The reasons are informal within-family insurance mechanisms that can alleviate some adverse effects of the latter. Our result is only seemingly different as we consider a wide range of micro-level shocks, from individual illness to economic shocks at the village level (whereas macro shocks occur at the country level). In particular, our evidence applies to micro shocks, which are regarded as having high impact and occurring in the fields of agriculture and economics. Its credibility seems to be further enhanced as the effects are particularly pronounced for less

insured and low income households. Our study, thus, sharpens earlier insights.

Beyond the macro-micro determinants, subjective assessment of well-being 
impacts risk aversion. Risk aversion increases if people regard their situation worse compared to the past or expect a worse living condition in the future. Overall, this study shows that the risk aversion of 384 people is systematically affected by major changes in the micro-level living conditions of the household as well as fluctuation of the macroeconomic environment.

An important aspect that we cannot measure well is whether changes in risk attitude are indeed temporal or permanent. Due to our data, which span changes over two or three years, we tend to interpret an impact on risk attitude as longer-term. However, it is not clear whether an adaption to shocks occurs. In the psychology literature, Burns et al. (2011) conducts a panel study to understand the trajectory of risk perception amidst the ongoing economic crisis. Their study shows that while peoples' risk aversion increased during the crisis, over time, it returned back to baseline level because people adapt to ongoing stimuli. As a result, they hypothesize that risk aversion follows an inverted Ucurve. However, this is only a first insight and a deeper understanding would certainly be desirable to make further inferences on the evolution of risk aversion over a much longer time period.

Finally, while we know that risk aversion does not seem to be stable over time and it is affected by the number of certain micro-shocks, it is interesting to investigate whether changes in risk attitude are also translated into risky behavior (i.e. more risk aversion resulting in the possible reduction of investment-related activities etc.). Future research should carry out deeper investigations about the impact of changes of individual risk attitude on risky behavior. 


\section{References}

Abdellaoui, M., Baillon, A., Placido, L., and Wakker, P. (2011). The rich domain of uncertainty: Source functions and their experimental implementation. American Economic Review, 101(2):695-723.

Andersen, S., Harrison, G. W., Lau, M. I., and Rutström, E. E. (2008). Lost in state space: Are preferences stable? International Economic Review, 49(3):1091-1112.

Andersson, O., Tyran, J.-R., Wengström, E., and Holm, H. J. (2016). Risk aversion relates to cognitive ability: Preference or noise? Journal of the European Economic Association, forthcoming.

Bchir, M. A. and Willinger, M. (2013). Does the exposure to natural hazards affect risk and time preferences? Some insights from a field experiment in peru. Lameta Working Paper, University of Montpellier.

Beauchamp, J., Cesarini, D., and Johannesson, M. (2012). The psychometric properties of measures of economic risk preferences. Working Paper, Harvard University.

Becketti, S., Gould, W., Lillard, L., and Welch, F. (1988). The panel study of income dynamics after fourteen years: An evaluation. Journal of Labor Economics, 6(4):472-492.

Binswanger, H. P. (1980). Attitudes toward risk: Experimental measurement in rural India. American Journal of Agricultural Economics, 62(3):395-407.

Brunnermeier, M. K. and Nagel, S. (2008). Do wealth fluctuations generate time-varying risk aversion? Micro-evidence on individuals' asset allocation. American Economic Review, 98(3):713-736.

Burns, W. J., Peters, E., and Slovic, P. (2012). Risk perception and the economic crisis: A longitudinal study of the trajectory of perceived risk. Risk analysis : An official publication of the Society for Risk Analysis, 32(4):659677. 
Callen, M., Isaqzadeh, M., Long, J. D., and Sprenger, C. D. (2014). Violence and risk preference: Experimental evidence from Afghanistan. American Economic Review, 104(1):123-148.

Calvet, L. E. and Sodini, P. (2014). Twin picks: Disentangling the determinants of risk-taking in household portfolios. Journal of Finance, 69(2):867906.

Cameron, L. and Shah, M. (2015). Risk-taking behavior in the wake of natural disasters. Journal of Human Resources, 50(2):484-515.

Chiappori, P.-A. and Paiella, M. (2011). Relative risk aversion is constant: Evidence from panel data. Journal of the European Economic Association, 9(6):1021-1052.

Chuang, Y. and Schechter, L. (2015). Stability of experimental and survey measures of risk, time, and social preferences: A review and some new results. Journal of Development Economics, 117(7):151-170.

Cohn, A., Engelmann, J., Fehr, E., and Maréchal, M. A. (2015). Evidence for countercyclical risk aversion: An experiment with financial professionals. American Economic Review, 105(2):860-885.

Croson, R. and Gneezy, U. (2009). Gender differences in preferences. Journal of Economic Literature, 47(2):448-474.

Delavande, A., Xavier, G., and McKenzie, D. (2011). Measuring expectations in developing countries: A critical review and new evidence. Journal of Development Economics, 94(2):151-16.

Dercon, S. (2002). Income risks, coping strategies, and safety nets. World Bank Research Observer, 47(2):141-166.

Dercon, S. and Christiaensen, L. (2011). Consumption risk, technology adoption and poverty traps: Evidence from Ethiopia. Journal of Development Economics, 96(2):159-173.

Dercon, S. and Krishnan, P. (2000). In sickness and in health: Risk sharing within households in rural Ethiopia. Journal of Political Economy, 108(4):688-727. 
Dohmen, T., Falk, A., Huffman, D., Sunde, U., Schupp, J., and Wagner, G. G. (2011). Individual risk attitudes: Measurement, determinants, and behavioral consequences. Journal of the European Economic Association, $9(3): 522-550$.

Donkers, B., Melenberg, B., and van Soest, A. (2001). Estimating risk attitudes using lotteries: A large sample approach. Journal of Risk and Uncertainty, 22(2):165-195.

Eckel, C., El-Gamal, M. A., and Wilson, R. K. (2009). Risk loving after the storm: A baysian-network study of hurricane Katrina evacuees. Journal of Economic Behavior and Organization, 69(2):110-124.

Falk, A., Becker, A., Dohmen, T., Huffman, D., and Sunde, U. (2016). The preference survey module: A validated instrument for measuring risk, time, and social preferences. mimeo, Bonn.

Fitzgerald, J., Gottschalk, P., and Moffitt, R. (1998). An analysis of sample attrition in panel data: The Michigan panel study of income dynamics. Journal of Human Resources, 33(2):251-299.

Gaudecker, H.-M. v., van Soest, A., and Wengstroem, E. (2011). Heterogeneity in risky choice behavior in a broad population. American Economic Review, 101(2):664-694.

Gertler, P. and Gruber, J. (2002). Insuring consumption against illness. American Economic Review, 92(1):51-70.

Guiso, L. and Paiella, M. (2008). Risk aversion, wealth, and background risk. Journal of the European Economic Association, 6(6):1109-1150.

Gusio, L., Sapienza, P., and Zingales, L. (2014). Time-varying risk aversion. National Bureau of Economic Research, Working Paper No.19284.

Hardeweg, B., Menkhoff, L., and Waibel, H. (2013). Experimentally validated survey evidence on individual risk attitudes in rural Thailand. Economic Development and Cultural Change, 61(4):859-888. 
Harrison, G. W., Humphrey, S. J., and Verschoor, A. (2010). Choice under uncertainty: Evidence from Ethiopia, India and Uganda. Economic Journal, 120(543):80-104.

Harrison, G. W., Lau, M. I., and Rutström, E. E. (2007). Estimating risk attitudes in Denmark: A field experiment. Scandinavian Journal of Economics, 109(2):341-368.

Heckman, J. J. (1979). Sample selection bias as a specification error. Econometrica, 47(1):153-161.

Hershey, J. C. and Schoemaker, P. J. H. (1985). Probability versus certainty equivalence methods in utility measurement: Are they equivalent? Management Science, 31(10):1213-1231.

Hey, J. D. (2001). Does repetition improve consistency? Experimental Economics, 4(1):5-54.

Hey, J. D. and Orme, C. (1994). Investigating generalizations of expected utility theory using experimental data. Econometrica, 62(6):1291-1326.

Hirshleifer, D. and Shumway, T. (2003). Good day sunshine: Stock returns and the weather. Journal of Finance, 58(3):1009-1032.

Holt, C. A. and Laury, S. K. (2002). Risk aversion and incentive effects. American Economic Review, 92(5):1644-1655.

Jalan, J. and Ravallion, M. (1999). Are the poor well-insured? Evidence on vulnerability to income risk in rural China. Journal of Development Economics, 58(1):61-81.

Jappelli, T. and Pistaferri, L. (2010). The consumption response to income changes. Annual Review of Economics, 2:479-506.

Malmendier, U. and Nagel, S. (2011). Depression babies: Do macroeconomic experiences affect risk taking? The Quarterly Journal of Economics, 126(1):373-416.

Meier, S. and Sprenger, C. D. (2015). Stability of time preferences. Review of Economics and Statistics, 97(2):273-286. 
Rabe-Hesketh, S. and Skrondal, A. (2012). Multilevel and Longitudinal Modeling Using Stata (Third Edition). Stata Press.

Sahm, C. (2012). How much does risk tolerance change? Quarterly Journal of Finance, 2(4):1-53.

Tanaka, T., Camerer, C. F., and Nguyen, Q. (2010). Risk and time preferences: Linking experimental and household survey data from Vietnam. American Economic Review, 100(1):557-571.

Townsend, R. M. (1994). Risk and insurance in village India. Econometrica, 62(3):539-591.

Vella, F. and Verbeek, M. (1999). Two-step estimation of panel data models with censored endogenous variables and selection bias. Journal of Econometrics, 90(239-263).

Vieider, F. M., Lefebvre, M., Bouchouicha, R., Chmura, T., Hakimov, R., Krawczyk, M., and Martinsson, P. (2015). Common components of risk and uncertainty attitudes across contexts and domains: Evidence from 30 countries. Journal of the European Economic Association, 13(3):421-452.

Volk, S., Thöni, C., and Ruigrok, W. (2012). Temporal stability and psychological foundations of cooperation preferences. Journal of Economic Behavior and Organization, 81(2):664-676.

Voors, M. J., Nillesen, E. E. M., Verwimp, P., Bulte, E. H., Lensink, R., and Soest, D. P. V. (2012). Violent conflict and behavior: A field experiment in Burundi. American Economic Review, 102(2):941-964.

Weber, M., Weber, E. U., and Nosic, A. (2013). Who takes risks when and why: Determinants of changes in investor risk taking. Review of Finance, $17(3): 847-883$.

Yesuf, M. and Bluffstone, R. A. (2009). Poverty, risk aversion, and path dependence in low-income countries: Experimental evidence from Ethiopia. American Journal of Agricultural Economics, 91(4):1022-1037. 
Figure 1: Histogram of minimum acceptable offer
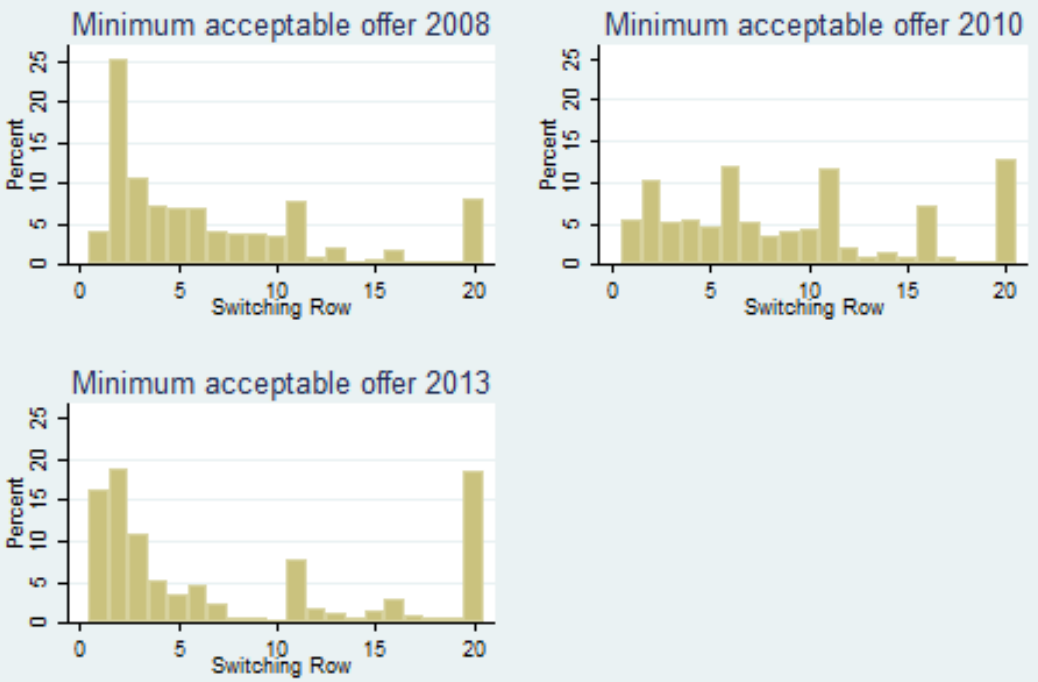

Figure 1: This figure reports the distribution of the experimental measure of risk aversion in 2008, 2010, and 2013 using a certainty equivalent task. In a nutshell, respondents make 20 decisions between a safe payoff and a lottery, where the lottery remains unchanged but the safe payoff increases steadily row by row. Further details on the experimental procedure are displayed in Appendix A.

Figure 2: Within-Subject Differences in CRRA

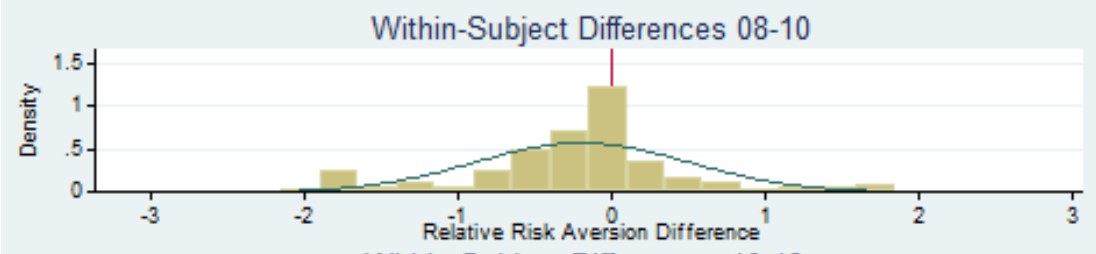

Within-Subject Differences 10-13

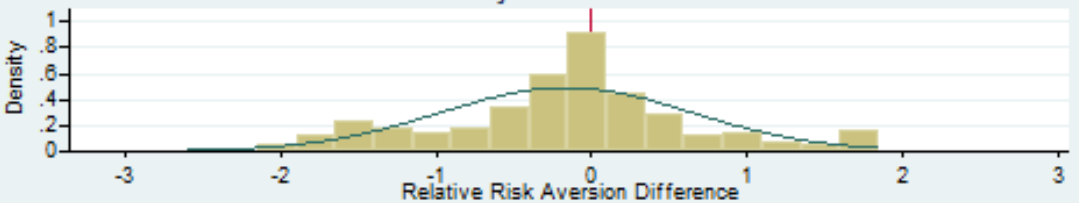

Within-Subject Differences 08-13

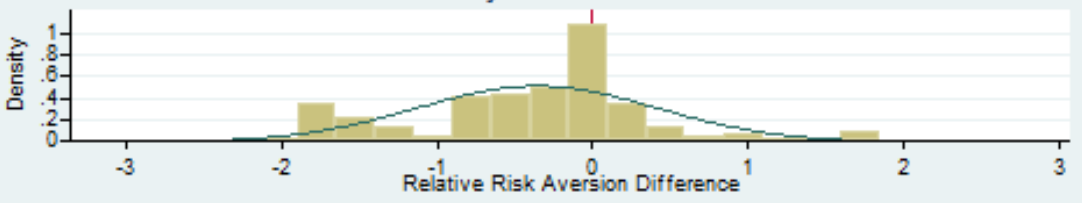

Figure 2: This figure shows the within-sample variation in the experimental task. The values show the difference in CRRA values of the switching row between 2008-2013, 2010-2013, and 2008-2010. 
Table 1.A: Summary Statistics for Full and Repeated Sample

\begin{tabular}{|c|c|c|c|c|c|c|c|}
\hline & (1) & $(2)$ & $(3)$ & $(4)$ & $(5)$ & $(6)$ & (7) \\
\hline & \multicolumn{3}{|c|}{ Participation in study } & \multicolumn{4}{|c|}{ Sample in Different Years } \\
\hline & (Full Sample) & (Repeated Sample) & (T-Test) & $(2008)$ & $(2010)$ & $(2013)$ & (T-Test) \\
\hline \multicolumn{8}{|c|}{ Panel A: Socio-demographics } \\
\hline Gender & $\begin{array}{c}0.58 \\
(0.49)\end{array}$ & $\begin{array}{c}0.59 \\
(0.49)\end{array}$ & 0.57 & $\begin{array}{c}0.57 \\
(0.50)\end{array}$ & $\begin{array}{c}0.59 \\
(0.49)\end{array}$ & $\begin{array}{c}0.59 \\
(0.49)\end{array}$ & 0.23 \\
\hline Age & $\begin{array}{c}52.36 \\
(13.35)\end{array}$ & $\begin{array}{c}54.33 \\
(11.84)\end{array}$ & 0.00 & $\begin{array}{c}50.75 \\
(13.02)\end{array}$ & $\begin{array}{c}52.00 \\
(12.84)\end{array}$ & $\begin{array}{c}54.43 \\
(13.97)\end{array}$ & 0.00 \\
\hline Height (cm) & $\begin{array}{c}157.12 \\
(9.01)\end{array}$ & $\begin{array}{l}157.87 \\
(8.99)\end{array}$ & 0.18 & $\begin{array}{l}158.11 \\
(10.66)\end{array}$ & $\begin{array}{c}158.80 \\
(7.90)\end{array}$ & $\begin{array}{l}158.20 \\
(8.13)\end{array}$ & 0.83 \\
\hline Farmer & $\begin{array}{c}0.63 \\
(0.48)\end{array}$ & $\begin{array}{c}0.67 \\
(0.47)\end{array}$ & 0.00 & $\begin{array}{c}0.60 \\
(0.49)\end{array}$ & $\begin{array}{c}0.62 \\
(0.49)\end{array}$ & $\begin{array}{c}0.69 \\
(0.46)\end{array}$ & 0.00 \\
\hline Public servant & $\begin{array}{c}0.03 \\
(0.16)\end{array}$ & $\begin{array}{c}0.02 \\
(0.12)\end{array}$ & 0.00 & $\begin{array}{c}0.03 \\
(0.18)\end{array}$ & $\begin{array}{c}0.02 \\
(0.15)\end{array}$ & $\begin{array}{c}0.02 \\
(0.15)\end{array}$ & 0.16 \\
\hline Self-employed & $\begin{array}{c}0.09 \\
(0.29)\end{array}$ & $\begin{array}{c}0.07 \\
(0.26)\end{array}$ & 0.00 & $\begin{array}{c}0.11 \\
(0.32)\end{array}$ & $\begin{array}{c}0.10 \\
(0.30)\end{array}$ & $\begin{array}{c}0.05 \\
(0.22)\end{array}$ & 0.00 \\
\hline Martial status & $\begin{array}{c}0.83 \\
(0.38)\end{array}$ & $\begin{array}{c}0.80 \\
(0.40)\end{array}$ & 0.01 & $\begin{array}{c}0.82 \\
(0.38)\end{array}$ & $\begin{array}{c}0.84 \\
(0.37)\end{array}$ & $\begin{array}{c}0.82 \\
(0.39)\end{array}$ & 0.75 \\
\hline Years of education & $\begin{array}{c}5.63 \\
(3.04)\end{array}$ & $\begin{array}{c}5.27 \\
(2.69)\end{array}$ & 0.00 & $\begin{array}{l}5.57 \\
(3.01)\end{array}$ & $\begin{array}{c}5.63 \\
(2.97)\end{array}$ & $\begin{array}{c}5.68 \\
(3.14)\end{array}$ & 0.48 \\
\hline Household size & $\begin{array}{c}4.09 \\
(1.75)\end{array}$ & $\begin{array}{c}3.90 \\
(1.74)\end{array}$ & 0.00 & $\begin{array}{c}4.13 \\
(1.79)\end{array}$ & $\begin{array}{c}4.09 \\
(1.76)\end{array}$ & $\begin{array}{l}4.04 \\
1.72\end{array}$ & 0.31 \\
\hline Health status & $\begin{array}{l}1.56 \\
(0.71)\end{array}$ & $\begin{array}{c}1.59 \\
(0.70)\end{array}$ & 0.08 & $\begin{array}{l}1.59 \\
(0.75)\end{array}$ & $\begin{array}{l}1.48 \\
(0.65)\end{array}$ & $\begin{array}{l}1.61 \\
0.73\end{array}$ & 0.47 \\
\hline Log per capita consumption & $\begin{array}{c}7.51 \\
(0.63)\end{array}$ & $\begin{array}{c}7.50 \\
(0.62)\end{array}$ & 0.78 & $\begin{array}{l}7.26 \\
(0.64)\end{array}$ & $\begin{array}{c}7.69 \\
(0.56)\end{array}$ & $\begin{array}{c}7.57 \\
(0.62)\end{array}$ & 0.00 \\
\hline Observations & 2691 & 1152 & & 942 & 900 & 849 & \\
\hline
\end{tabular}

Notes: This table shows means of individual and household characteristics. Standard deviations are reported in parenthesis. Column (3) shows p-values for T-tests between Column (1) and Column (2). Column (7) shows p-values for T-tests between columns (6) and $(4)$. 
Table 1.B: Summary Statistics for Full and Repeated Sample

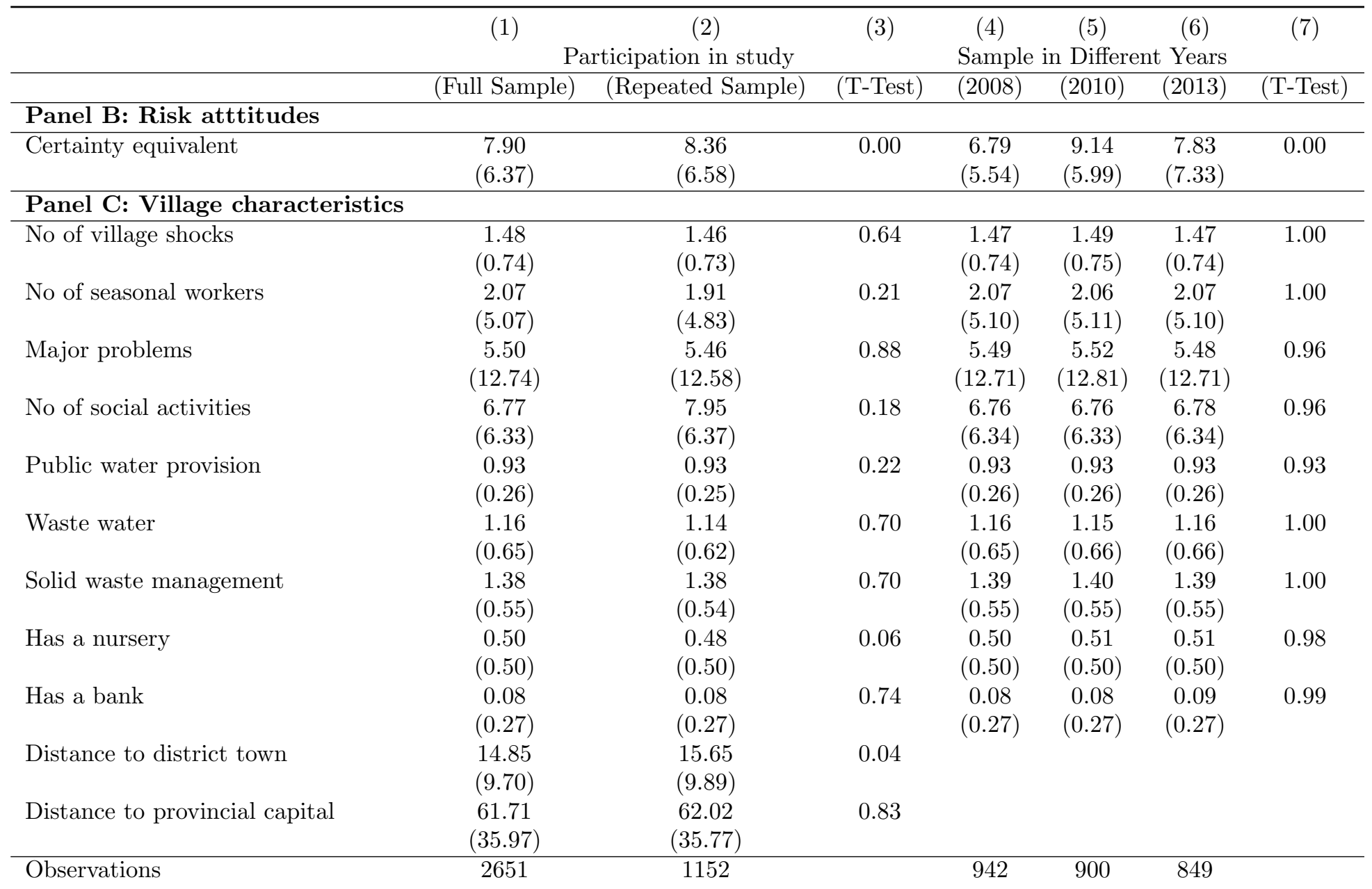

Notes: This table shows means and standard deviations of risk attitude and village characteristics. Column (3) shows p-values for Ttests between Column (1) and Column (2). Column (7) shows p-values for T-tests between columns (6) and (4). 
Table 2: Summary Statistics for Full and Repeated Sample

\begin{tabular}{|c|c|c|c|c|c|c|c|}
\hline & (1) & $(2)$ & $(3)$ & $(4)$ & $(5)$ & (6) & (7) \\
\hline & \multicolumn{3}{|c|}{ Participation in study } & \multicolumn{4}{|c|}{ Sample in Different Years } \\
\hline & (Full Sample) & (Repeated Sample) & (T-Test) & $(2008)$ & $(2010)$ & $(2013)$ & (T-Test) \\
\hline \multicolumn{8}{|l|}{ Panel A: Micro-level shocks } \\
\hline No of micro-level shocks & $\begin{array}{c}1.50 \\
(1.50)\end{array}$ & $\begin{array}{c}1.46 \\
(1.51)\end{array}$ & 0.27 & $\begin{array}{c}1.69 \\
(1.59)\end{array}$ & $\begin{array}{c}1.60 \\
(1.57)\end{array}$ & $\begin{array}{c}1.18 \\
(1.25)\end{array}$ & 0.00 \\
\hline No of high impact shocks & $\begin{array}{c}0.66 \\
(0.94)\end{array}$ & $\begin{array}{c}0.67 \\
(0.92)\end{array}$ & 0.40 & $\begin{array}{c}0.80 \\
(1.01)\end{array}$ & $\begin{array}{c}0.54 \\
(0.86)\end{array}$ & $\begin{array}{c}0.62 \\
(0.91)\end{array}$ & 0.00 \\
\hline No of medium impact shocks & $\begin{array}{c}0.49 \\
(0.80)\end{array}$ & $\begin{array}{c}0.48 \\
(0.77)\end{array}$ & 0.48 & $\begin{array}{c}0.59 \\
(0.88)\end{array}$ & $\begin{array}{c}0.42 \\
(0.73)\end{array}$ & $\begin{array}{c}0.46 \\
(0.78)\end{array}$ & 0.00 \\
\hline No of low impact shocks & $\begin{array}{c}0.09 \\
(0.33)\end{array}$ & $\begin{array}{c}0.08 \\
(0.28)\end{array}$ & 0.02 & $\begin{array}{c}0.12 \\
(0.38)\end{array}$ & $\begin{array}{c}0.08 \\
(0.31)\end{array}$ & $\begin{array}{c}0.07 \\
(0.29)\end{array}$ & 0.00 \\
\hline No of demographic shocks & $\begin{array}{c}0.34 \\
(0.61)\end{array}$ & $\begin{array}{c}0.31 \\
(0.59)\end{array}$ & 0.02 & $\begin{array}{c}0.44 \\
(0.74)\end{array}$ & $\begin{array}{c}0.25 \\
(0.47)\end{array}$ & $\begin{array}{c}0.34 \\
(0.56)\end{array}$ & 0.00 \\
\hline No of social shocks & $\begin{array}{c}0.26 \\
(0.52)\end{array}$ & $\begin{array}{c}0.26 \\
(0.53)\end{array}$ & 0.98 & $\begin{array}{c}0.26 \\
(0.54)\end{array}$ & $\begin{array}{c}0.21 \\
(0.48)\end{array}$ & $\begin{array}{c}0.31 \\
(0.55)\end{array}$ & 0.08 \\
\hline No of agricultural shocks & $\begin{array}{c}0.50 \\
(0.79)\end{array}$ & $\begin{array}{c}0.49 \\
(0.77)\end{array}$ & 0.55 & $\begin{array}{c}0.64 \\
(0.91)\end{array}$ & $\begin{array}{c}0.45 \\
(0.70)\end{array}$ & $\begin{array}{c}0.41 \\
(0.69)\end{array}$ & 0.00 \\
\hline No of economic shocks & $\begin{array}{c}0.22 \\
(0.49)\end{array}$ & $\begin{array}{c}0.21 \\
(0.47)\end{array}$ & 0.25 & $\begin{array}{c}0.32 \\
(0.57)\end{array}$ & $\begin{array}{c}0.17 \\
(0.42)\end{array}$ & $\begin{array}{c}0.15 \\
(0.43)\end{array}$ & 0.00 \\
\hline No of covariate shocks & $\begin{array}{c}0.62 \\
(0.94)\end{array}$ & $\begin{array}{c}0.59 \\
(0.89)\end{array}$ & 0.14 & $\begin{array}{c}0.83 \\
(1.09)\end{array}$ & $\begin{array}{c}0.52 \\
(0.85)\end{array}$ & $\begin{array}{c}0.49 \\
(0.80)\end{array}$ & 0.00 \\
\hline No of idiosyncratic shocks & $\begin{array}{c}0.67 \\
(0.89)\end{array}$ & $\begin{array}{c}0.64 \\
(0.89)\end{array}$ & 0.11 & $\begin{array}{c}0.82 \\
(1.04)\end{array}$ & $\begin{array}{c}0.50 \\
(0.71)\end{array}$ & $\begin{array}{c}0.69 \\
(0.86)\end{array}$ & 0.01 \\
\hline \multicolumn{8}{|l|}{ Panel B: Subjective well-being measures } \\
\hline Perceived ill-being (Past) & $\begin{array}{c}2.39 \\
(0.85)\end{array}$ & $\begin{array}{c}2.43 \\
(0.86)\end{array}$ & 0.07 & $\begin{array}{c}2.61 \\
(0.92)\end{array}$ & $\begin{array}{c}2.30 \\
(0.76)\end{array}$ & $\begin{array}{c}2.23 \\
(0.80)\end{array}$ & 0.00 \\
\hline Expected ill-being (Future) & $\begin{array}{c}2.62 \\
(1.01)\end{array}$ & $\begin{array}{c}2.67 \\
(1.04)\end{array}$ & 0.03 & $\begin{array}{c}2.96 \\
(1.09)\end{array}$ & $\begin{array}{c}2.55 \\
(0.91)\end{array}$ & $\begin{array}{c}2.30 \\
(0.88)\end{array}$ & 0.00 \\
\hline Observations & 2651 & 1152 & & 942 & 900 & 849 & \\
\hline
\end{tabular}

Notes: This table shows means of subjective assessment of well-being measures and self-reported micro-level shocks. Standard deviations are reported in parenthesis. Column (3) shows p-values for T-tests for equal means between Column (1) and Column (2). Column (7) shows p-values for T-tests for equal means between columns (6) and (4). 
Table 3: Determinants of Changes in Risk Aversion

\begin{tabular}{|c|c|c|c|c|c|}
\hline & $\begin{array}{c}\text { (1) } \\
\text { CRRA }\end{array}$ & $\begin{array}{c}(2) \\
\text { CRRA }\end{array}$ & $\begin{array}{c}(3) \\
\text { CRRA }\end{array}$ & $\begin{array}{c}(4) \\
\text { CRRA }\end{array}$ & $\begin{array}{c}(5) \\
\text { CRRA }\end{array}$ \\
\hline Marital status & $\begin{array}{l}0.179^{*} \\
(0.100)\end{array}$ & $\begin{array}{l}0.185^{*} \\
(0.104)\end{array}$ & $\begin{array}{c}0.216^{* *} \\
(0.096)\end{array}$ & $\begin{array}{c}0.133 \\
(0.103)\end{array}$ & $\begin{array}{c}0.171^{*} \\
(0.101)\end{array}$ \\
\hline Years of education & $\begin{array}{l}-0.008 \\
(0.214)\end{array}$ & $\begin{array}{c}-0.053 \\
(0.214)\end{array}$ & $\begin{array}{c}0.010 \\
(0.184)\end{array}$ & $\begin{array}{l}-0.026 \\
(0.201)\end{array}$ & $\begin{array}{c}-0.028 \\
(0.184)\end{array}$ \\
\hline Household size & $\begin{array}{l}-0.037 \\
(0.023)\end{array}$ & $\begin{array}{l}-0.019 \\
(0.023)\end{array}$ & $\begin{array}{l}-0.035 \\
(0.022)\end{array}$ & $\begin{array}{l}-0.021 \\
(0.024)\end{array}$ & $\begin{array}{l}-0.010 \\
(0.024)\end{array}$ \\
\hline Health status & $\begin{array}{l}-0.002 \\
(0.042)\end{array}$ & $\begin{array}{c}0.006 \\
(0.040)\end{array}$ & $\begin{array}{c}0.002 \\
(0.041)\end{array}$ & $\begin{array}{l}-0.008 \\
(0.043)\end{array}$ & $\begin{array}{l}-0.007 \\
(0.040)\end{array}$ \\
\hline Log per capita consumption & $\begin{array}{c}-0.103^{* *} \\
(0.045)\end{array}$ & $\begin{array}{l}-0.003 \\
(0.054)\end{array}$ & $\begin{array}{c}-0.101^{* *} \\
(0.045)\end{array}$ & $\begin{array}{l}-0.066 \\
(0.046)\end{array}$ & $\begin{array}{l}-0.008 \\
(0.056)\end{array}$ \\
\hline Number of micro-level shocks & & & $\begin{array}{c}0.062^{* * *} \\
(0.016)\end{array}$ & & $\begin{array}{c}0.048^{* * *} \\
(0.016)\end{array}$ \\
\hline Expected ill-being (Future) & & & & $\begin{array}{c}0.089 * * * \\
(0.028)\end{array}$ & $\begin{array}{c}0.079^{* * *} \\
(0.028)\end{array}$ \\
\hline Perceived ill-being (Past) & & & & $\begin{array}{c}0.086^{* * *} \\
(0.020)\end{array}$ & $\begin{array}{c}0.060^{* * *} \\
(0.022)\end{array}$ \\
\hline Year dummy 2010 & & $\begin{array}{c}-0.200^{* * *} \\
(0.048)\end{array}$ & & & $\begin{array}{c}-0.138^{* * *} \\
(0.048)\end{array}$ \\
\hline Year dummy 2013 & & $\begin{array}{c}-0.215^{* * *} \\
(0.052)\end{array}$ & & & $\begin{array}{c}-0.112^{*} \\
(0.061)\end{array}$ \\
\hline Constant & $\begin{array}{c}1.194 \\
(1.227)\end{array}$ & $\begin{array}{c}0.741 \\
(1.250)\end{array}$ & $\begin{array}{c}0.950 \\
(1.075)\end{array}$ & $\begin{array}{c}0.573 \\
(1.194)\end{array}$ & $\begin{array}{c}0.181 \\
(1.115)\end{array}$ \\
\hline R-Squared Within & 0.02 & 0.05 & 0.04 & 0.08 & 0.09 \\
\hline District Fixed Effects & Yes & Yes & Yes & Yes & Yes \\
\hline Observations & 384 & 384 & 384 & 361 & 361 \\
\hline
\end{tabular}

Notes: This table reports results on within-changes in levels of risk aversion using the midpoint of the CRRA interval in all three waves. Controls include a selected set of individual and household characteristics, subjective assessment of well-being measures and micro-level shocks. We include year and district fixed effects. Standard errors are in parenthesis and clustered on the village level. Female, height, and age drop out. ${ }^{* * *},{ }^{*}$ and ${ }^{*}$ denote significance at the $1 \%, 5 \%$ and $10 \%$ levels, respectively. 
Table 4: Determinants of Changes in Risk Preferences (Micro-level shocks)

\begin{tabular}{|c|c|c|c|}
\hline & $\begin{array}{c}(1) \\
\text { CRRA }\end{array}$ & $\begin{array}{c}(2) \\
\text { CRRA }\end{array}$ & $\begin{array}{c}(3) \\
\text { CRRA }\end{array}$ \\
\hline Marital status & $\begin{array}{c}0.148 \\
(0.093)\end{array}$ & $\begin{array}{c}0.164 \\
(0.100)\end{array}$ & $\begin{array}{c}0.167 \\
(0.101)\end{array}$ \\
\hline Years of education & $\begin{array}{l}-0.075 \\
(0.164)\end{array}$ & $\begin{array}{l}-0.042 \\
(0.143)\end{array}$ & $\begin{array}{l}-0.053 \\
(0.185)\end{array}$ \\
\hline Household size & $\begin{array}{l}-0.014 \\
(0.024)\end{array}$ & $\begin{array}{l}-0.012 \\
(0.023)\end{array}$ & $\begin{array}{l}-0.008 \\
(0.024)\end{array}$ \\
\hline Health status & $\begin{array}{l}-0.009 \\
(0.039)\end{array}$ & $\begin{array}{l}-0.015 \\
(0.039)\end{array}$ & $\begin{array}{l}-0.008 \\
(0.040)\end{array}$ \\
\hline Log per capita consumption & $\begin{array}{l}-0.015 \\
(0.055)\end{array}$ & $\begin{array}{c}0.007 \\
(0.055)\end{array}$ & $\begin{array}{l}-0.003 \\
(0.055)\end{array}$ \\
\hline Expected ill-being (Future) & $\begin{array}{c}0.079^{* * *} \\
(0.028)\end{array}$ & $\begin{array}{c}0.081^{* * *} \\
(0.028)\end{array}$ & $\begin{array}{c}0.079 * * * \\
(0.028)\end{array}$ \\
\hline Perceived ill-being (Past) & $\begin{array}{c}0.060^{* * *} \\
(0.022)\end{array}$ & $\begin{array}{c}0.051^{* *} \\
(0.022)\end{array}$ & $\begin{array}{c}0.060^{* * *} \\
(0.022)\end{array}$ \\
\hline No of demographic shocks & $\begin{array}{c}0.008 \\
(0.032)\end{array}$ & & \\
\hline No of social shocks & $\begin{array}{c}0.049 \\
(0.046)\end{array}$ & & \\
\hline No of agricultural shocks & $\begin{array}{c}0.064^{* *} \\
(0.027)\end{array}$ & & \\
\hline No of economic shocks & $\begin{array}{c}0.175^{* * *} \\
(0.045)\end{array}$ & & \\
\hline No of high impact shocks & & $\begin{array}{c}0.113^{* * *} \\
(0.024)\end{array}$ & \\
\hline No of medium impact shocks & & $\begin{array}{c}0.043^{*} \\
(0.025)\end{array}$ & \\
\hline No of low impact shocks & & $\begin{array}{l}-0.024 \\
(0.071)\end{array}$ & \\
\hline No of covariate shocks & & & $\begin{array}{c}0.047^{* *} \\
(0.019)\end{array}$ \\
\hline No of idiosyncratic shocks & & & $\begin{array}{c}0.037 \\
(0.023)\end{array}$ \\
\hline Year Dummy 2010 & $\begin{array}{c}-0.091^{*} \\
(0.050)\end{array}$ & $\begin{array}{c}-0.097^{* *} \\
(0.048)\end{array}$ & $\begin{array}{c}-0.112^{* *} \\
(0.051)\end{array}$ \\
\hline Year Dummy 2013 & $\begin{array}{l}-0.093 \\
(0.059)\end{array}$ & $\begin{array}{c}-0.106^{*} \\
(0.060)\end{array}$ & $\begin{array}{c}-0.116^{*} \\
(0.061)\end{array}$ \\
\hline Constant & $\begin{array}{c}0.473 \\
(1.013)\end{array}$ & $\begin{array}{c}0.140 \\
(0.913)\end{array}$ & $\begin{array}{c}0.275 \\
(1.119)\end{array}$ \\
\hline $\begin{array}{l}\text { R-Squared Within } \\
\text { District Fixed Effects } \\
\text { Observations }\end{array}$ & $\begin{array}{c}0.111 \\
\text { Yes } \\
384\end{array}$ & $\begin{array}{c}0.109 \\
\text { Yes } \\
384\end{array}$ & $\begin{array}{c}0.087 \\
\text { Yes } \\
384\end{array}$ \\
\hline
\end{tabular}

Notes: This table reports results on within-changes in levels of risk aversion using the midpoint of the CRRA interval in all three waves. Controls include a selected set of individual and household characteristics, subjective assessment of well-being measures and various types of micro-level shocks. We include year and district fixed effects. Standard errors are in parenthesis and clustered on the village level. Female, height, and age drop out. ${ }^{* * *}, * *$ and $*$ denote significance at the $1 \%, 5 \%$ and $10 \%$ levels, respectively. 
Table 5.A: Impact of Shocks on Changes in Risk Preferences for Vulnerable Subpopulations

\begin{tabular}{lccc}
\hline & $(1)$ & $(2)$ & $(3)$ \\
& $0-2$ Insurance & $3-5$ Insurances & $>5$ Insurance \\
\hline Panel A: Number of Insurances & & & \\
\hline No of demographic shocks & 0.070 & -0.044 & -0.159 \\
No of social shocks & $(0.068)$ & $(0.062)$ & $(0.147)$ \\
No of agricultural shocks & 0.042 & -0.004 & 0.130 \\
& $(0.091)$ & $(0.077)$ & $(0.115)$ \\
No of economic shocks & $0.091^{*}$ & -0.002 & 0.035 \\
& $(0.047)$ & $(0.047)$ & $(0.087)$ \\
\hline R-Squared Within & $0.165^{*}$ & $0.223^{*}$ & 0.180 \\
\hline \hline No high impact shocks & $(0.096)$ & $(0.113)$ & $(0.123)$ \\
\hline No medium impact shocks & 0.139 & 0.244 & 0.258 \\
\hline No of low impact shocks & $0.157^{* * *}$ & -0.007 & $0.106 * *$ \\
& $(0.037)$ & $(0.041)$ & $(0.049)$ \\
\hline R-Squared Within & $0.086^{*}$ & 0.065 & 0.049 \\
\hline \hline No of covariate shocks & $(0.046)$ & $(0.073)$ & $(0.151)$ \\
No of idiosyncratic shocks & -0.086 & -0.093 & -0.307 \\
& $(0.137)$ & $(0.195)$ & $(0.349)$ \\
\hline R-Squared Within & 0.158 & 0.214 & 0.240 \\
\hline Controls & $0.069^{*}$ & 0.021 & -0.028 \\
Dime Fixed Effects & $(0.038)$ & $(0.039)$ & $(0.081)$ \\
\hline Observations & 0.074 & -0.025 & 0.056 \\
& $(0.047)$ & $(0.048)$ & $(0.071)$ \\
\hline
\end{tabular}

Notes: This table reports results on within-changes in levels of risk aversion using the midpoint of the CRRA interval in all three waves. Controls include years of education, household size, marital status and log per capital consumption. We include year and district fixed effects. Standard errors are in parenthesis and clustered on the village level. Female, height, and age drop out. ${ }^{* * *},{ }^{* *}$ and ${ }^{*}$ denote significance at the $1 \%, 5 \%$ and $10 \%$ levels, respectively. 
Table 5.B: Impact of Shocks on Changes in Risk Preferences for Vulnerable Subpopulations

\begin{tabular}{|c|c|c|c|}
\hline & $\begin{array}{c}(1) \\
\text { Bottom } 20 \%\end{array}$ & $\begin{array}{c}(2) \\
40-60 \%\end{array}$ & $\begin{array}{c}(3) \\
\text { Top } 20 \%\end{array}$ \\
\hline \multicolumn{4}{|l|}{ Panel B: Income Levels } \\
\hline No of demographic shocks & $\begin{array}{l}-0.027 \\
(0.088)\end{array}$ & $\begin{array}{l}-0.267 \\
(0.169)\end{array}$ & $\begin{array}{l}-0.062 \\
(0.147)\end{array}$ \\
\hline No of social shocks & $\begin{array}{l}-0.115 \\
(0.127)\end{array}$ & $\begin{array}{r}0.395^{* *} \\
(0.179)\end{array}$ & $\begin{array}{c}0.176 \\
(0.135)\end{array}$ \\
\hline No of agricultural shocks & $\begin{array}{c}0.061 \\
(0.065)\end{array}$ & $\begin{array}{l}0.193^{*} \\
(0.107)\end{array}$ & $\begin{array}{c}0.086 \\
(0.076)\end{array}$ \\
\hline No of economic shocks & $\begin{array}{c}0.322^{* *} \\
(0.145)\end{array}$ & $\begin{array}{c}0.010 \\
(0.172)\end{array}$ & $\begin{array}{c}0.226 \\
(0.168)\end{array}$ \\
\hline R-Squared Within & 0.244 & 0.299 & 0.197 \\
\hline No high impact shocks & $\begin{array}{l}0.127^{* *} \\
(0.049)\end{array}$ & $\begin{array}{c}0.132 \\
(0.081)\end{array}$ & $\begin{array}{c}0.150^{* *} \\
(0.066)\end{array}$ \\
\hline No medium impact shocks & $\begin{array}{l}-0.064 \\
(0.069)\end{array}$ & $\begin{array}{c}0.101 \\
(0.076)\end{array}$ & $\begin{array}{c}0.008 \\
(0.060)\end{array}$ \\
\hline No of low impact shocks & $\begin{array}{c}-0.246 \\
(0.236)\end{array}$ & $\begin{array}{c}0.245 \\
(0.189)\end{array}$ & $\begin{array}{c}-0.287^{*} \\
(0.171)\end{array}$ \\
\hline R-Squared Within & 0.229 & 0.189 & 0.161 \\
\hline No of covariate shocks & $\begin{array}{c}0.025 \\
(0.045)\end{array}$ & $\begin{array}{c}0.033 \\
(0.071)\end{array}$ & $\begin{array}{c}0.058 \\
(0.050)\end{array}$ \\
\hline No of idiosyncratic shocks & $\begin{array}{c}0.039 \\
(0.051)\end{array}$ & $\begin{array}{c}0.104 \\
(0.076)\end{array}$ & $\begin{array}{c}0.054 \\
(0.079)\end{array}$ \\
\hline R-Squared Within & 0.183 & 0.152 & 0.119 \\
\hline Controls & Yes & Yes & Yes \\
\hline Year Fixed Effects & Yes & Yes & Yes \\
\hline District Fixed Effects & Yes & Yes & Yes \\
\hline Observations & 384 & 384 & 384 \\
\hline
\end{tabular}

Notes: This table reports results on within-changes in levels of risk aversion using the midpoint of the CRRA interval in all three waves. Controls include years of education, household size, marital status and log per capital consumption. We include year and district fixed effects. Standard errors are in parenthesis and clustered on the village level. Female, height, and age drop out. ${ }^{* * *},{ }^{* *}$ and ${ }^{*}$ denote significance at the $1 \%, 5 \%$ and $10 \%$ levels, respectively. 
Table 6: Stability of Risk Preferences over Time

\begin{tabular}{|c|c|c|c|}
\hline & $\begin{array}{c}(1) \\
\text { CRRA } 2013\end{array}$ & $\begin{array}{c}(2) \\
\text { CRRA } 2013\end{array}$ & $\begin{array}{c}(3) \\
\text { CRRA } 2013\end{array}$ \\
\hline CRRA2008 & $\begin{array}{c}0.147^{* * * *} \\
(0.043)\end{array}$ & $\begin{array}{c}0.138^{* * * *} \\
(0.046)\end{array}$ & $\begin{array}{c}0.137^{* *} \\
(0.066)\end{array}$ \\
\hline Female & & $\begin{array}{c}0.094^{* *} \\
(0.046)\end{array}$ & $\begin{array}{l}-0.015 \\
(0.069)\end{array}$ \\
\hline Age & & $\begin{array}{c}0.004^{* *} \\
(0.002)\end{array}$ & $\begin{array}{c}0.005 \\
(0.003)\end{array}$ \\
\hline Height (cm) & & $\begin{array}{c}-0.000 \\
(0.002)\end{array}$ & $\begin{array}{l}-0.000 \\
(0.005)\end{array}$ \\
\hline Farmer & & $\begin{array}{l}-0.019 \\
(0.048)\end{array}$ & $\begin{array}{c}0.050 \\
(0.070)\end{array}$ \\
\hline Self-employed & & $\begin{array}{c}-0.165^{*} \\
(0.085)\end{array}$ & $\begin{array}{c}0.249^{* *} \\
(0.115)\end{array}$ \\
\hline Public servant & & $\begin{array}{c}-0.596^{* * *} \\
(0.130)\end{array}$ & $\begin{array}{l}-0.411^{*} \\
(0.215)\end{array}$ \\
\hline Martial status & & $\begin{array}{c}-0.150^{* * *} \\
(0.049)\end{array}$ & $\begin{array}{l}-0.012 \\
(0.075)\end{array}$ \\
\hline Years of education & & $\begin{array}{l}-0.009 \\
(0.008)\end{array}$ & $\begin{array}{l}-0.010 \\
(0.011)\end{array}$ \\
\hline Household size & & $\begin{array}{c}-0.028^{* *} \\
(0.012)\end{array}$ & $\begin{array}{l}-0.024 \\
(0.021)\end{array}$ \\
\hline Health status & & $\begin{array}{c}0.015 \\
(0.028)\end{array}$ & $\begin{array}{c}0.008 \\
(0.038)\end{array}$ \\
\hline Log per capita consumption & & $\begin{array}{c}-0.071^{* *} \\
(0.034)\end{array}$ & $\begin{array}{l}-0.042 \\
(0.052)\end{array}$ \\
\hline Constant & $\begin{array}{c}0.040 \\
(0.029) \\
\end{array}$ & $\begin{array}{c}0.612 \\
(0.427) \\
\end{array}$ & $\begin{array}{c}0.392 \\
(0.875) \\
\end{array}$ \\
\hline Estimator & Pooled OLS & Pooled OLS & Heckman \\
\hline Selection equation & No & No & Yes \\
\hline R-Squared & 0.01 & 0.07 & 0.06 \\
\hline Observations & 471 & 471 & 471 \\
\hline
\end{tabular}

Notes: This table reports results on within-changes in levels of risk aversion using the midpoint of the CRRA interval only in year 2013. it reports coefficients of OLS and Heckman 2-Step regressions. All socio-economic variables are 2008 values. Standard errors are in parenthesis and clustered on a village level. ***, ** and $*$ denote significance at the $1 \%, 5 \%$ and $10 \%$ levels, respectively. 
Table 7: Selection Bias

\begin{tabular}{|c|c|c|c|}
\hline & $\begin{array}{c}(1) \\
\text { No Shock }\end{array}$ & $\begin{array}{c}(2) \\
\text { Has a Shock }\end{array}$ & $\begin{array}{c}(3) \\
\text { T-Test }\end{array}$ \\
\hline \multicolumn{4}{|l|}{ Panel A: Village Characteristics } \\
\hline No of village shocks & $\begin{array}{c}1.43 \\
(0.66)\end{array}$ & $\begin{array}{c}1.50 \\
(0.76)\end{array}$ & 0.16 \\
\hline No of seasonal workers & $\begin{array}{l}1.96 \\
(3.05)\end{array}$ & $\begin{array}{c}2.11 \\
(4.06)\end{array}$ & 0.54 \\
\hline Major problems & $\begin{array}{c}5.05 \\
(10.93)\end{array}$ & $\begin{array}{c}5.70 \\
(13.45)\end{array}$ & 0.24 \\
\hline No of social cultural activities & $\begin{array}{c}6.60 \\
(6.29)\end{array}$ & $\begin{array}{c}6.85 \\
(6.35)\end{array}$ & 0.38 \\
\hline Public water provision & $\begin{array}{l}1.08 \\
(0.27)\end{array}$ & $\begin{array}{c}1.07 \\
(0.25)\end{array}$ & 0.24 \\
\hline Waste water & $\begin{array}{l}1.16 \\
(0.65)\end{array}$ & $\begin{array}{l}1.16 \\
(0.65)\end{array}$ & 0.99 \\
\hline Has nursery & $\begin{array}{l}1.49 \\
(0.50)\end{array}$ & $\begin{array}{c}1.51 \\
(0.50)\end{array}$ & 0.48 \\
\hline Has bank & $\begin{array}{c}1.91 \\
(0.28)\end{array}$ & $\begin{array}{c}1.91 \\
(0.26)\end{array}$ & 0.27 \\
\hline \multicolumn{4}{|l|}{ Panel B: Individual Characteristics } \\
\hline CRRA & $\begin{array}{c}0.30 \\
(0.61)\end{array}$ & $\begin{array}{c}0.35 \\
(0.56)\end{array}$ & 0.04 \\
\hline Female & $\begin{array}{c}0.55 \\
(0.49)\end{array}$ & $\begin{array}{c}0.60 \\
(0.49)\end{array}$ & 0.02 \\
\hline Age & $\begin{array}{c}53.33 \\
(13.86)\end{array}$ & $\begin{array}{c}51.92 \\
(13.11)\end{array}$ & 0.01 \\
\hline Marital status & $\begin{array}{c}0.83 \\
(0.37)\end{array}$ & $\begin{array}{c}0.82 \\
(0.38)\end{array}$ & 0.61 \\
\hline Years of education & $\begin{array}{c}5.73 \\
(3.16)\end{array}$ & $\begin{array}{c}5.59 \\
(2.98)\end{array}$ & 0.28 \\
\hline Log per capita wealth & $\begin{array}{c}9.01 \\
(1.13)\end{array}$ & $\begin{array}{c}9.02 \\
(1.03)\end{array}$ & 0.89 \\
\hline Log per capita consumption & $\begin{array}{c}7.49 \\
(0.63)\end{array}$ & $\begin{array}{c}7.52 \\
(0.63)\end{array}$ & 0.32 \\
\hline Household size & $\begin{array}{c}3.91 \\
(1.67)\end{array}$ & $\begin{array}{c}4.16 \\
(1.77)\end{array}$ & 0.00 \\
\hline Health status & $\begin{array}{c}1.49 \\
(0.66)\end{array}$ & $\begin{array}{c}1.59 \\
(0.72)\end{array}$ & 0.00 \\
\hline
\end{tabular}

Notes: This table shows means of individual, household and village characteristics. Standard deviations are reported in parenthesis. 
Table 8: Determinants of Changes in Risk Preferences (Income Effects)

\begin{tabular}{|c|c|c|c|}
\hline & $\begin{array}{c}(1) \\
\text { CRRA }\end{array}$ & $\begin{array}{c}(2) \\
\text { CRRA }\end{array}$ & $\begin{array}{c}(3) \\
\text { CRRA }\end{array}$ \\
\hline Marital status & $\begin{array}{c}0.169 \\
(0.150)\end{array}$ & $\begin{array}{c}0.163 \\
(0.150)\end{array}$ & $\begin{array}{c}0.091 \\
(0.136)\end{array}$ \\
\hline Years of education & $\begin{array}{l}-0.173 \\
(0.104)\end{array}$ & $\begin{array}{l}-0.179 \\
(0.138)\end{array}$ & $\begin{array}{l}-0.190 \\
(0.136)\end{array}$ \\
\hline Household size & $\begin{array}{c}0.023 \\
(0.029)\end{array}$ & $\begin{array}{c}0.040 \\
(0.028)\end{array}$ & $\begin{array}{c}0.044 \\
(0.028)\end{array}$ \\
\hline Health status & $\begin{array}{l}-0.020 \\
(0.052)\end{array}$ & $\begin{array}{l}-0.022 \\
(0.051)\end{array}$ & $\begin{array}{l}-0.027 \\
(0.051)\end{array}$ \\
\hline Log per capita consumption & $\begin{array}{c}-0.096^{*} \\
(0.051)\end{array}$ & $\begin{array}{l}-0.025 \\
(0.070)\end{array}$ & $\begin{array}{l}-0.025 \\
(0.070)\end{array}$ \\
\hline Number of economic shocks & $\begin{array}{c}0.165^{* * *} \\
(0.056)\end{array}$ & $\begin{array}{c}0.147^{* *} \\
(0.059)\end{array}$ & $\begin{array}{c}0.143^{* *} \\
(0.058)\end{array}$ \\
\hline Expected ill-being (Future) & $\begin{array}{c}0.065 \\
(0.044)\end{array}$ & $\begin{array}{c}0.063 \\
(0.044)\end{array}$ & $\begin{array}{c}0.055 \\
(0.044)\end{array}$ \\
\hline Perceived ill-being (Past) & $\begin{array}{c}0.071^{* *} \\
(0.031)\end{array}$ & $\begin{array}{l}0.064^{*} \\
(0.036)\end{array}$ & $\begin{array}{c}0.072^{* *} \\
(0.035)\end{array}$ \\
\hline Total financial aid & $\begin{array}{c}0.004 \\
(0.004)\end{array}$ & $\begin{array}{c}0.004 \\
(0.004)\end{array}$ & $\begin{array}{c}0.005 \\
(0.004)\end{array}$ \\
\hline Income loss due to shocks & $\begin{array}{c}0.000 \\
(0.000)\end{array}$ & $\begin{array}{c}0.000 \\
(0.000)\end{array}$ & $\begin{array}{c}0.000 \\
(0.000)\end{array}$ \\
\hline Year Dummy 2010 & & $\begin{array}{c}-0.131^{*} \\
(0.067)\end{array}$ & $\begin{array}{l}-0.123^{*} \\
(0.067)\end{array}$ \\
\hline Year Dummy 2013 & & $\begin{array}{l}-0.020 \\
(0.094)\end{array}$ & $\begin{array}{l}-0.019 \\
(0.092)\end{array}$ \\
\hline Constant & $\begin{array}{l}1.387^{*} \\
(0.753)\end{array}$ & $\begin{array}{c}0.911 \\
(0.853)\end{array}$ & $\begin{array}{c}1.008 \\
(0.814)\end{array}$ \\
\hline R-Squared Within & 0.096 & 0.140 & 0.154 \\
\hline District Fixed Effects & No & No & Yes \\
\hline Observations & 384 & 384 & 384 \\
\hline
\end{tabular}

Notes: This table reports results on within-changes in levels of risk aversion using the midpoint of the CRRA interval in all three waves. Controls include a selected set of individual and household characteristics, subjective assessment of well-being measures and micro-level economic shocks. We include year and district fixed effects. Standard errors are in parenthesis and clustered on the village level. Female, height, and age drop out. ***,** and * denote significance at the $1 \%, 5 \%$ and $10 \%$ levels, respectively. 
Table 9: Determinants of Changes in Risk Aversion using Switching Rows

\begin{tabular}{|c|c|c|c|c|}
\hline & $\begin{array}{c}(1) \\
\text { SWR }\end{array}$ & $\begin{array}{c}(2) \\
\text { SWR }\end{array}$ & $\begin{array}{c}(3) \\
\text { SWR }\end{array}$ & $\begin{array}{c}(4) \\
\text { SWR }\end{array}$ \\
\hline Marital status & $\begin{array}{c}-2.448^{* *} \\
(1.060)\end{array}$ & $\begin{array}{c}-1.935^{*} \\
(1.100)\end{array}$ & $\begin{array}{c}-2.028^{*} \\
(1.118)\end{array}$ & $\begin{array}{l}-1.758 \\
(1.124)\end{array}$ \\
\hline Years of education & $\begin{array}{c}1.290 \\
(1.852)\end{array}$ & $\begin{array}{c}1.539 \\
(1.953)\end{array}$ & $\begin{array}{c}1.404 \\
(1.870)\end{array}$ & $\begin{array}{c}1.387 \\
(1.875)\end{array}$ \\
\hline Household size & $\begin{array}{c}0.370 \\
(0.240)\end{array}$ & $\begin{array}{c}0.223 \\
(0.262)\end{array}$ & $\begin{array}{c}0.078 \\
(0.257)\end{array}$ & $\begin{array}{c}0.066 \\
(0.257)\end{array}$ \\
\hline Health status & $\begin{array}{l}-0.010 \\
(0.425)\end{array}$ & $\begin{array}{c}0.089 \\
(0.435)\end{array}$ & $\begin{array}{c}0.196 \\
(0.422)\end{array}$ & $\begin{array}{c}0.201 \\
(0.422)\end{array}$ \\
\hline Log per capita consumption & $\begin{array}{c}1.377^{* * *} \\
(0.518)\end{array}$ & $\begin{array}{l}1.001^{*} \\
(0.532)\end{array}$ & $\begin{array}{c}0.086 \\
(0.596)\end{array}$ & $\begin{array}{c}0.110 \\
(0.598)\end{array}$ \\
\hline Number of micro-level shocks & $\begin{array}{c}-0.537^{* * *} \\
(0.167)\end{array}$ & $\begin{array}{c}-0.419^{* *} \\
(0.169)\end{array}$ & $\begin{array}{c}-0.425^{* *} \\
(0.172)\end{array}$ & $\begin{array}{c}-0.422^{* *} \\
(0.173)\end{array}$ \\
\hline Expected ill-being (Future) & & $\begin{array}{c}-0.943^{* * *} \\
(0.305)\end{array}$ & $\begin{array}{c}-0.838^{* * *} \\
(0.318)\end{array}$ & $\begin{array}{c}-0.826^{* *} \\
(0.319)\end{array}$ \\
\hline Perceived ill-being (Past) & & $\begin{array}{c}-0.847^{* * *} \\
(0.229)\end{array}$ & $\begin{array}{c}-0.646^{* * *} \\
(0.246)\end{array}$ & $\begin{array}{c}-0.681^{* * *} \\
(0.249)\end{array}$ \\
\hline Year dummy 2010 & & & $\begin{array}{c}2.072^{* * *} \\
(0.561)\end{array}$ & $\begin{array}{c}2.044^{* * *} \\
(0.563)\end{array}$ \\
\hline Year dummy 2013 & & & $\begin{array}{c}0.879 \\
(0.641)\end{array}$ & $\begin{array}{c}0.852 \\
(0.638)\end{array}$ \\
\hline Constant & $\begin{array}{c}-7.358 \\
(11.130)\end{array}$ & $\begin{array}{c}-1.401 \\
(11.807)\end{array}$ & $\begin{array}{c}4.874 \\
(11.294)\end{array}$ & $\begin{array}{c}4.054 \\
(11.342)\end{array}$ \\
\hline R-Squared Within & 0.027 & 0.067 & 0.089 & 0.093 \\
\hline District Fixed Effect & Yes & Yes & Yes & Yes \\
\hline Observations & 384 & 384 & 384 & 384 \\
\hline
\end{tabular}

Notes: This table reports results on individual switching rows from the certainty equivalent task in all three waves. Controls include a selected set of individual and household characteristics, subjective assessment of well-being measures and microlevel shocks. We include year and district fixed effects. Standard errors are in parenthesis and clustered on the village level. Female, height, and age drop out. ***, ** and ${ }^{*}$ denote significance at the $1 \%, 5 \%$ and $10 \%$ levels, respectively. 
Table 10: Determinants of Changes in Risk Preferences using Switching Rows (Micro-level shocks)

\begin{tabular}{|c|c|c|c|}
\hline & $\begin{array}{c}(1) \\
\text { SWR }\end{array}$ & $\begin{array}{c}(2) \\
\text { SWR }\end{array}$ & $\begin{array}{c}(3) \\
\text { SWR }\end{array}$ \\
\hline Marital status & $\begin{array}{l}-1.553 \\
(1.059)\end{array}$ & $\begin{array}{l}-1.730 \\
(1.101)\end{array}$ & $\begin{array}{l}-1.731 \\
(1.125)\end{array}$ \\
\hline Years of education & $\begin{array}{c}1.852 \\
(1.620)\end{array}$ & $\begin{array}{c}1.524 \\
(1.384)\end{array}$ & $\begin{array}{c}1.572 \\
(1.888)\end{array}$ \\
\hline Household size & $\begin{array}{c}0.109 \\
(0.253)\end{array}$ & $\begin{array}{c}0.092 \\
(0.249)\end{array}$ & $\begin{array}{c}0.050 \\
(0.257)\end{array}$ \\
\hline Health status & $\begin{array}{c}0.227 \\
(0.411)\end{array}$ & $\begin{array}{c}0.306 \\
(0.406)\end{array}$ & $\begin{array}{c}0.220 \\
(0.421)\end{array}$ \\
\hline Log per capita consumption & $\begin{array}{c}0.189 \\
(0.586)\end{array}$ & $\begin{array}{l}-0.051 \\
(0.590)\end{array}$ & $\begin{array}{c}0.068 \\
(0.594)\end{array}$ \\
\hline Expected ill-being (Future) & $\begin{array}{c}-0.834^{* * *} \\
(0.312)\end{array}$ & $\begin{array}{c}-0.853^{* * *} \\
(0.310)\end{array}$ & $\begin{array}{c}-0.833^{* *} \\
(0.320)\end{array}$ \\
\hline Perceived ill-being (Past) & $\begin{array}{c}-0.681^{* * *} \\
(0.247)\end{array}$ & $\begin{array}{c}-0.569^{* *} \\
(0.251)\end{array}$ & $\begin{array}{c}-0.679^{* * *} \\
(0.249)\end{array}$ \\
\hline No of demographic shocks & $\begin{array}{c}-0.135 \\
(0.325)\end{array}$ & & \\
\hline No of social shocks & $\begin{array}{l}-0.391 \\
(0.511)\end{array}$ & & \\
\hline No of agricultural shocks & $\begin{array}{c}-0.723^{* *} \\
(0.284)\end{array}$ & & \\
\hline No of economic shocks & $\begin{array}{c}-1.921^{* * *} \\
(0.520)\end{array}$ & & \\
\hline No of high impact shocks & & $\begin{array}{c}-1.298^{* * *} \\
(0.249)\end{array}$ & \\
\hline No of medium impact shocks & & $\begin{array}{c}-0.374 \\
(0.263)\end{array}$ & \\
\hline No of low impact shocks & & $\begin{array}{c}0.102 \\
(0.726)\end{array}$ & \\
\hline No of covariate shocks & & & $\begin{array}{c}-0.404^{*} \\
(0.213)\end{array}$ \\
\hline No of idiosyncratic shocks & & & $\begin{array}{c}-0.403 \\
(0.257)\end{array}$ \\
\hline Year Dummy 2010 & $\begin{array}{c}1.519 * * \\
(0.579)\end{array}$ & $\begin{array}{c}1.593^{* * *} \\
(0.556)\end{array}$ & $\begin{array}{c}1.792^{* * *} \\
(0.590)\end{array}$ \\
\hline Year Dummy 2013 & $\begin{array}{c}0.569 \\
(0.626)\end{array}$ & $\begin{array}{c}0.739 \\
(0.622)\end{array}$ & $\begin{array}{c}0.878 \\
(0.635)\end{array}$ \\
\hline Constant & $\begin{array}{c}1.243 \\
(9.988)\end{array}$ & $\begin{array}{c}4.635 \\
(8.976)\end{array}$ & $\begin{array}{c}3.416 \\
(11.393)\end{array}$ \\
\hline $\begin{array}{l}\text { R-Squared Within } \\
\text { District Fixed Effects } \\
\text { Observations }\end{array}$ & $\begin{array}{c}0.129 \\
\text { Yes } \\
384\end{array}$ & $\begin{array}{l}0.119 \\
\text { Yes } \\
384\end{array}$ & $\begin{array}{c}0.092 \\
\text { Yes } \\
384\end{array}$ \\
\hline
\end{tabular}

Notes: This table reports results on individual switching rows from the certainty equivalent task in all three waves. Controls include a selected set of individual and household characteristics, subjective assessment of well-being measures and various types of micro-level shocks. We include year and district fixed effects. Standard errors are in parenthesis and clustered on the village level. Female, height, and age drop out. ***,** and $*$ denote significance at the $1 \%, 5 \%$ and $10 \%$ levels, respectively. 
Table 11: Determinants of Changes in Risk Preferences eliminating exterme responses

\begin{tabular}{|c|c|c|c|}
\hline & $\begin{array}{c}(1) \\
\text { Upper Bound CRRA }\end{array}$ & $\begin{array}{c}(2) \\
\text { Upper Bound CRRA }\end{array}$ & $\begin{array}{c}(3) \\
\text { Upper Bound CRRA }\end{array}$ \\
\hline Marital status & $\begin{array}{c}0.106 \\
(0.084)\end{array}$ & $\begin{array}{c}0.121 \\
(0.085)\end{array}$ & $\begin{array}{c}0.122 \\
(0.087)\end{array}$ \\
\hline Years of education & $\begin{array}{c}0.084 \\
(0.161)\end{array}$ & $\begin{array}{c}0.097 \\
(0.157)\end{array}$ & $\begin{array}{c}0.096 \\
(0.162)\end{array}$ \\
\hline Household size & $\begin{array}{l}-0.016 \\
(0.018)\end{array}$ & $\begin{array}{l}-0.015 \\
(0.017)\end{array}$ & $\begin{array}{l}-0.014 \\
(0.018)\end{array}$ \\
\hline Health status & $\begin{array}{l}-0.036 \\
(0.026)\end{array}$ & $\begin{array}{l}-0.042 \\
(0.026)\end{array}$ & $\begin{array}{l}-0.035 \\
(0.027)\end{array}$ \\
\hline Log per capita consumption & $\begin{array}{l}-0.021 \\
(0.040)\end{array}$ & $\begin{array}{l}-0.009 \\
(0.040)\end{array}$ & $\begin{array}{l}-0.013 \\
(0.040)\end{array}$ \\
\hline Expected ill-being (Future) & $\begin{array}{l}0.042^{*} \\
(0.021)\end{array}$ & $\begin{array}{l}0.043^{* *} \\
(0.021)\end{array}$ & $\begin{array}{l}0.042^{*} \\
(0.022)\end{array}$ \\
\hline Perceived ill-being (Past) & $\begin{array}{c}0.045^{* * *} \\
(0.015)\end{array}$ & $\begin{array}{l}0.039 * * \\
(0.015)\end{array}$ & $\begin{array}{c}0.045^{* * *} \\
(0.015)\end{array}$ \\
\hline No of demographic shocks & $\begin{array}{l}-0.004 \\
(0.023)\end{array}$ & & \\
\hline No of social shocks & $\begin{array}{c}0.014 \\
(0.032)\end{array}$ & & \\
\hline No of agricultural shocks & $\begin{array}{c}0.030 \\
(0.020)\end{array}$ & & \\
\hline No of economic shocks & $\begin{array}{c}0.098^{* * *} \\
(0.031)\end{array}$ & & \\
\hline No of high impact shocks & & $\begin{array}{c}0.067^{* * *} \\
(0.017)\end{array}$ & \\
\hline No of medium impact shocks & & $\begin{array}{c}0.009 \\
(0.018)\end{array}$ & \\
\hline No of low impact shocks & & $\begin{array}{c}0.018 \\
(0.051)\end{array}$ & \\
\hline No of covariate shocks & & & $\begin{array}{c}0.022 \\
(0.015)\end{array}$ \\
\hline No of idiosyncratic shocks & & & $\begin{array}{c}0.011 \\
(0.016)\end{array}$ \\
\hline Year Dummy 2010 & $\begin{array}{c}-0.117^{* * *} \\
(0.039)\end{array}$ & $\begin{array}{c}-0.116^{* * *} \\
(0.038)\end{array}$ & $\begin{array}{c}-0.129 * * * \\
(0.040)\end{array}$ \\
\hline Year Dummy 2013 & $\begin{array}{c}-0.210^{* * *} \\
(0.041)\end{array}$ & $\begin{array}{c}-0.219^{* * *} \\
(0.041)\end{array}$ & $\begin{array}{c}-0.225^{* * *} \\
(0.042)\end{array}$ \\
\hline Constant & $\begin{array}{l}-0.079 \\
(0.902)\end{array}$ & $\begin{array}{l}-0.235 \\
(0.885)\end{array}$ & $\begin{array}{l}-0.197 \\
(0.921)\end{array}$ \\
\hline R-Squared Within & 0.162 & 0.164 & 0.148 \\
\hline District Fixed Effects & Yes & Yes & Yes \\
\hline Observations & 369 & 369 & 369 \\
\hline
\end{tabular}

Notes: This table reports results on within-changes in levels of risk aversion using the midpoint of the CRRA interval in all three waves but excluding the most risk-averse responses. Controls include a selected set of individual and household characteristics, subjective assessment of well-being measures and various types of micro-level shocks. We include year and district fixed effects. Standard errors are in parenthesis and clustered on the village level. Female, height, and age drop out. ${ }^{* * *}, * *$ and $*$ denote significance at the $1 \%, 5 \%$ and $10 \%$ levels, respectively. 


\section{Appendices}

To accompany "Determinants of Risk Aversion over Time: Experimental Evidence"

Appendix A: Details of Risk Elicitation Task

Appendix B: Description of Variables 


\section{Appendix A Details of Risk Elicitation Task}

In our data collection process for the experiment, we tried to keep the enumerator instructions as short and simple as possible in order to facilitate the understanding.

1. Certainty equivalent experiment: This is game 1 . It has 20 rows. In each row a decision has to be made. In each row we would like you to choose option A or option B. Option A is a certain amount of THB. It starts with 0 and goes up by 10 THB in every row. Option B is a lottery where a coin is thrown. If 'King' falls you win 300 Baht. If 'Palace' falls you get nothing. (Enumerator shows the coin). Please make your choice of Option A or B for each row. If this game is selected to be played with real money, you will be asked to draw a number from a bag. The bag contains the numbers 1 to 20 for the 20 rows. We will play with real money according to your choice. For example: If you draw the number X (Enumerator ID) from the bag, we play the game at this row for money. That means: If you chose option A you will receive (THB). If you chose option B we will toss a coin. If 'King' you win 300 Baht. If 'Palace' you win nothing. 
Table A1: Certainty Equivalent Task

\begin{tabular}{|l|l|l||l|l|}
\hline Row & Option A & Tick Box & Tick Box & Option B \\
\hline 1 & 0 & & & $300: 0$ \\
\hline 2 & 10 & & & $300: 0$ \\
\hline 3 & 20 & & & $300: 0$ \\
\hline 4 & 30 & & & $300: 0$ \\
\hline 5 & 40 & & & $300: 0$ \\
\hline 6 & 50 & & & $300: 0$ \\
\hline 7 & 60 & & & $300: 0$ \\
\hline 8 & 70 & & & $300: 0$ \\
\hline 9 & 80 & & & $300: 0$ \\
\hline 10 & 90 & & & $300: 0$ \\
\hline 11 & 100 & & & $300: 0$ \\
\hline 12 & 110 & & & $300: 0$ \\
\hline 13 & 120 & & & $300: 0$ \\
\hline 14 & 130 & & & $300: 0$ \\
\hline 15 & 140 & & & $300: 0$ \\
\hline 16 & 150 & & & $300: 0$ \\
\hline 17 & 160 & & $300: 0$ \\
\hline 18 & 170 & & $300: 0$ \\
\hline 19 & 180 & & & $300: 0$ \\
\hline 20 & 190 & & & \\
\hline
\end{tabular}




\section{Appendix B Description of Variables}

\section{B.1 Individual and Household Characteristics}

Female is a dummy variable. It takes the value 1 for female and 0 for male.

Age is the respondents' age in years.

Height is respondents' height in $\mathrm{cm}$.

Years of education is denoted as years in eduation.

Marital status is a dummy variable. It takes the value 1 if married and 0 otherwise.

Household size is the headcount of persons who are living in the household for at least 180 days.

Health status asks the question: How healthy do you feel? $1=$ feel good; $2=$ manageable; $3=$ sick.

Number of insurances is the total sum of voluntary insurances of the household.

LPCC is the log per capita consumption and it refers to the natural logarithm of household consumption per day divided by OECD adult equivalents $\mathrm{AE}$ ( $\mathrm{AE}=$ $1+0.7^{*}($ adults- 1$)+0.5^{*}$ children $)$.

Farmer is a dummy variable. It takes the value 1 for being a farmer and 0 otherwise.

Self-employed is a dummy variable. It takes the value 1 for being self-employed and 0 otherwise.

\section{B.2 Micro-level shocks and well-being measures}

Perceived Ill-being (Past) asks the question: Do you think your household is better off than 5 years ago? $1=$ Much better off; $2=$ Better off; $3=$ Same; $4=$ Worse off; $5=$ Much worse off

Expected Ill-being (Future) asks the question: Do you think your household 
will be better off in 5 years? $1=$ Much better off; $2=$ Better off; $3=$ Same; $4=$ Worse off; $5=$ Much worse off.

No of demographic shocks is the sum of these self-reported experienced shocks:

Household member left the household

Illness of household member

Person joined the household

No of social shocks is the sum of these self-reported experienced shocks:

Accident

Conflict with neighbours in the village

Household was cheated

Household damage

Law suit

Money spent for ceremony in the household

Relatives/friends stopped sending money

Theft

No of agricultural shocks is the sum of these self-reported experienced shocks:

Crop pests

Drought

Flooding of agricultural land

Landslide, erosion

Livestock disease

Snow/ice rain

Storage pests, incl. rats

Storm

Unusually heavy rainfall

No idiosyncratic shocks is the sum of these self-reported experienced shocks which affected the household only or some of the households in the village:

Accident 
Collapse of business

Conflict of neighbour

Death of household member

Illness of household member

Strong increase of interest rate on loans

Household was cheated

Household Damage

Household member left the household

Illness of household member

Job loss (agricultural)

Job loss (non-agricultural)

Landslide, Erosion

Law suit

Livestock Disease

Money spent for ceremony in the household

Person joined the household

Relatives/Friends stopped sending money

Supporting others

Theft

Unable to pay back loan

No of covariate shocks is the sum of these self-reported experienced shocks which affected the entire village or district:

Snow / ice rain

Storage pests (including rats)

Storm

Strong decrease of prices for Output

Strong increase of prices for Input

Unusually heavy rainfall 
Flooding of agricultural land

Drought

Crop pests

Change in market regulations

\section{B.3 Village characteristics}

No of village shocks is the reported number of shocks a village experienced by the village head.

No of seasonal workers is the number of seasonal workers.

Major problems asks the question: Are there major problems in the village? $1=$ violence; $2=$ drug abuse/trafficking; $3=$ human trafficking; $4=$ epidemics; $5=$ politics

No of social cultural activities asks the question: What are the major social and cultural agricultural activities in the village?

Community meeting

Village radio system

Sport event, specify type of sport

Traditional festivals, specify festival

Festival related to Buddhist tradition

Public Water Provision asks the question: Is there a Public water supply available? Dummy for 1 is if the village has public water provision and 0 otherwise.

Waste Water asks the question: What is the main kind of waste water disposal? $1=$ discharge to the ground; $2=$ discharge to pond; $3=$ waste water pipes.

Solid waste management asks the question: What is the main kind of solid waste ? $1=$ burn; $2=$ dumping site; $3=$ public disposal.

Has nursery is a dummy for 1 if the village has a nursery and 0 otherwise.

Has bank is a dummy for 1 if the village has a bank and 0 otherwise. 
Distance to district town is the travel distance from the district town in $\mathrm{km}$.

Distance to provincial capital is the travel distance from the provincial capital in $\mathrm{km}$. 